\title{
The Existence of Mathematic Visual and Knowledge in Painting Art from Past to Present
}

\author{
Hatice Karadogan \\ Istanbul, Turkey \\ E-mail: haticemate@gmail.com
}

\begin{abstract}
The aim of this study is to give information about the relationship between mathematics and painting and also to show the existence of mathematics on sample pictures. The subject has been researched within the scope of the use of Painting Art in mathematics in its historical development. In some periods, the knowledge of mathematics and in some periods, the forms and symbols of mathematics were included in the picture. It is seen that the artists unwittingly show the effects of mathematics in their works. It is mentioned that the concepts of perspective and golden ratio of mathematics are important in the painting art of the Renaissance period. Before the Renaissance, the 19th century and after, the knowledge and visuals of mathematics can be seen in the painting.

The results of the study, the knowledge and visuals of mathematics have been observed in the art of painting in every period and the artist's use of mathematics in his works, either knowingly or unknowingly, is shown with sample pictures and diagrams.
\end{abstract}

Keywords: Mathematics, Picture, Form, Perspective

DOI: $10.7176 /$ JSTR/7-03-05

\section{Geçmişten Günümüze Resim Sanatında Matematik Görsel Ve Bilgisinin Varlığı}

\begin{abstract}
Özet
Bu çalışmanın amacı, matematiğin resim sanatı ile ilişkisi hakkında bilgi vermek ve aynı zamanda örnek resimler üzerinde matematiğin varlığını göstermektir. Resim Sanatının tarihi gelişimi içerisinde matematikte yararlanması kapsamında konu araştırılmıştır. Bazı dönemler matematiğin bilgisi bazı dönemlerde ise matematiğin form ve sembolleri resimde yer almıştır. Sanatçıların farkında olmadan matematiğin etkilerini eserlerinde gösterdikleri görülmektedir. Rönesans dönemi resim sanatında, matematiğin perspektif ve altın oran kavramlarının önemsendiğine değinilmektedir. Rönesans öncesi, 19.yy ve sonrasında matematiğin bilgisi ve görsellerinin resimde varlığı görülmektedir.

Çalışmanın sonuçları, matematiğin bilgi ve görsellerinin her dönem resim sanatında varlığ gözlemlenmiş ve sanatçının bilerek ya da bilmeyerek eserlerinde matematiği kullandıkları örnek resim ve şemalarla gösterilmiştir.
\end{abstract}

Anahtar Kelimeler: Matematik, Resim, Form, Perspektif

\section{GíRiş}

Matematik ve resim sanatının işbirliği ilk uygarlıklarda başlamış, dönem dönem matematik görselleri ve bilgisi resim sanatında kullanılmıştır. Tarih öncesi insanı, uygarlıklarının gelişimlerine paralel olarak, gereksinmelerini ifade etmek için farklı ifade şekillerine ihtiyaç duymuşlardır. Sayı saymaya, hesap yapmaya, ölçmeye ihtiyaç duymaya başlamalarıyla resimli yazıların önemi artmış her bir şekil ya da ifade, bir kavram ya da söz grubunun yerine kullanılmaya başlanmıştır. Matematiğin görselleri olan

38 | P a g e

www.iiste.org 
semboller ve geometrik formlar; taşlara, kemiklere, mağara duvarlarına, tabletlere, papirüs isimli kâğıtlara, kitaplara ve daha sonra duvar resimlerine (fresk) yapılmıştır. Böylece, doğayı ve yaşamlarını yalın biçimler, soyut çizgiler ve zaman zaman da sembollerle ifade etmeye başlamışlardır. Uygarlıkların gelişimine paralel olarak; yazının bulunması ve takip eden dönemlerde matematik kendi dilini oluşturmuş bir bilim olmuş ve resim yüzeyinde kopmuştur. Buna rağmen resim sanatında matematik bilgisi ve formları görülmeye devam etmiştir. İlk bulgularda, sayı saymak için matematik, kaydetmek için resim kullanılması, aynı amaç için işbirliği içinde olduklarını göstermektedir.

Her dönemin, resim sanatında matematiğin varlığı farklı biçimlerde olmuştur. İlk mağara duvar resimleri ve kemikler üzerindeki çentiklerde, Sümer tabletlerinde, Misır hiyerogliflerinde bugün kullandığımız matematiksel sembollerin birçoğu görülmektedir. Yunan, Roma ve Bizans sanatında da matematiksel form ve semboller kullanılmıştır. Rönesans döneminde ise matematik bilgisine önem verilmiş; ölçü, altın oran, bilimsel perspektif, geometrik kurgu gibi kavramlar resimde uygulanmıştır.19.yy sonlarına doğru resim sanatında, ışığın renk üzerindeki etkisinden dolayı, soyutlamalar başlamıştır. Buna ek olarak 20.yüzyılda Albert Einstein'ın bilimdeki buluşları ve Sigmund Freud'un bilinçaltı kuramı ile sanatta bilinçaltı, içgüdü, zihin, ruh gibi kavramlar tartışılmış bu sanatçıları etkilemiş̧tir. Ekspresyonizm, Fütürizm, Kübizm, Soyut Sanat, Dadaizm, Konstrüktivizm, Süprematizm, Metafizik, Sürrealizm, Minimalizm, Op-Art, Kavramsal Sanat gibi avangart akımlar çoğu eş zamanlı olarak resim sanatında yer almışlar ve zaman zaman matematikten yararlanmışlardır. Rönesansta önem verilen bilimsel perspektifle derinlik yanılsamasına bu dönemde karşı çıkılmıştır. Cézanne'ın bütün biçimleri geometrik formlarla ifade etmesi ve renklerle hacimsellik sağlaması, Kübistlerin figürleri düşündükleri gibi resmetmeleri zaman boyutunu da nesnenin etrafında dolaşıyormuş gibi her yüzeyini resme aktarmaları ve figürlerin gerçeğe benzememesi soyut sanatın habercisi olmuştur. Kandinsky ile geometrik soyut formlar resim yüzeyinde görülmüş ve bu geometrik formlar uzaya doğru gidiyormuş gibi perspektifli gösterilmiştir. Konstrüktivizimde, her şeyin geometrik bir oran ve ölçü içinde bulunduğu savunulmuş ve sanatsal esinlenmeden çok matematik bilgisiyle eserler tasarlanmıştır. Konstrüktivist sanatçılar cetvel ve pergel kullanarak kendilerine özgü soyut kompozisyonlar düzenlemişlerdir. Süprematizm de ise, tuvalin beyaz zemini ile simgelenen sonsuzluk ve kozmos eserlerinde yansitılmıştır. Dördüncü boyut olan zaman boyutu Kübizmle başlamış, takip eden dönemlerde çok boyutluluk kavramları resimde sonsuzluğun ve sınırsızlığın ifadesi olmuştur. Çoklu perspektifi eserlerinde kullanan Maurits Cornelius Escher, ayrıca imkânsız, paradoks, simetri, fraktal gibi matematiğin diğer kavramlarını ve bilgisini de kullanmıştır.

\section{MATEMATIKKSEL FORM VE BİLGISINIIN RESIM SANATINDA VARLIĞI 1.Matematiksel Görsellerin Resimde Varlığı}

Tarih öncesi çağlarda yazı henüz bilinmediğinde resim önemli bir iletişim aracıdır. İlk uygarlıklarla birlikte kemikler üzerindeki çentikler (Görsel 1), mağara duvarlarındaki resimlerinde nokta, çizgi, spiral, helezonik form, iç içe çemberler gibi matematiksel formlar görülmektedir.( Görsel 2.-3.)Ayrica hayvan figürlerinin büyüklü küçüklü kullanımı ve aynı formun belli bir oranda küçük ve büyük yapılması matematiğin bilgi olarak varlığının kanıtlarıdır. Sümer yazısının bulunmasıyla, matematiksel görseller birçok amaçla yüzeler de görülmeye devam etmiştir.

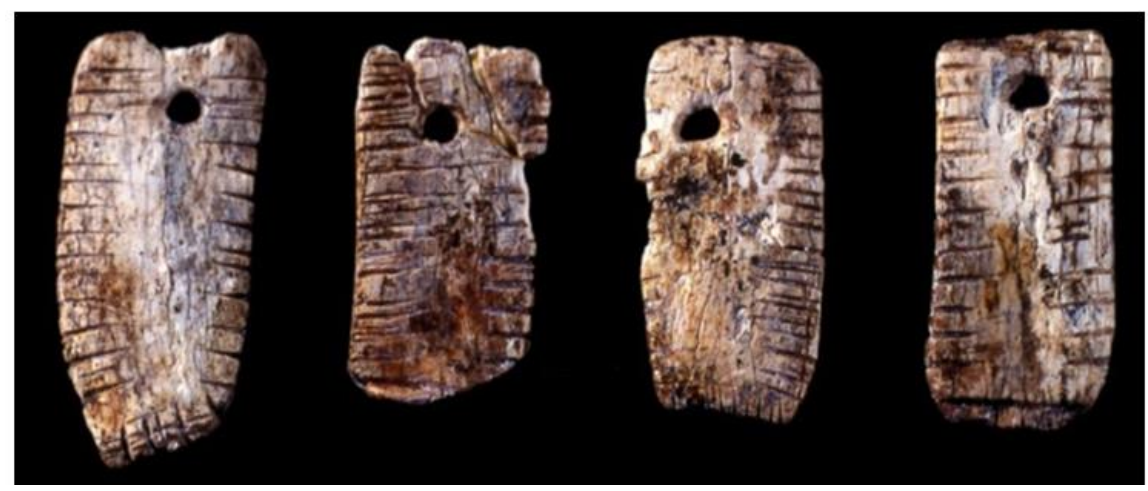

Görsel 1: Altamira Mağarasında bulunan hayvan kemikleri ve üzerinde görülen çentikler 


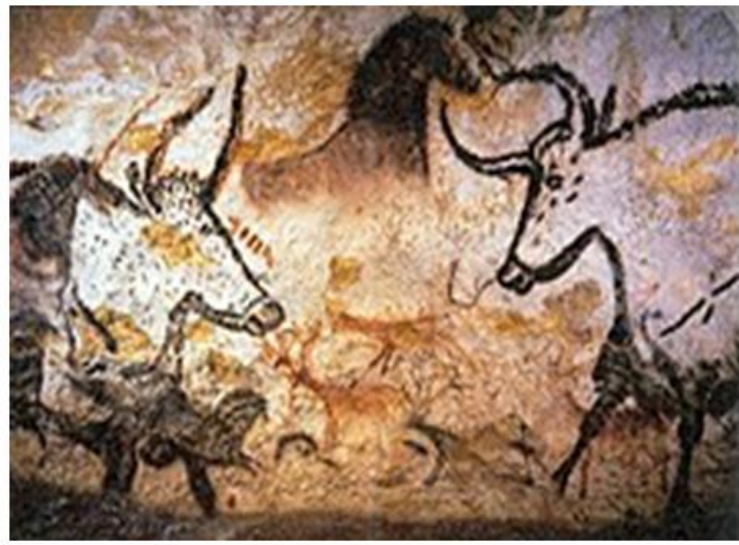

Görsel 2: Lascaux Mağarası, Fransa, https://en.wikipedia.org/wiki/Lascaux

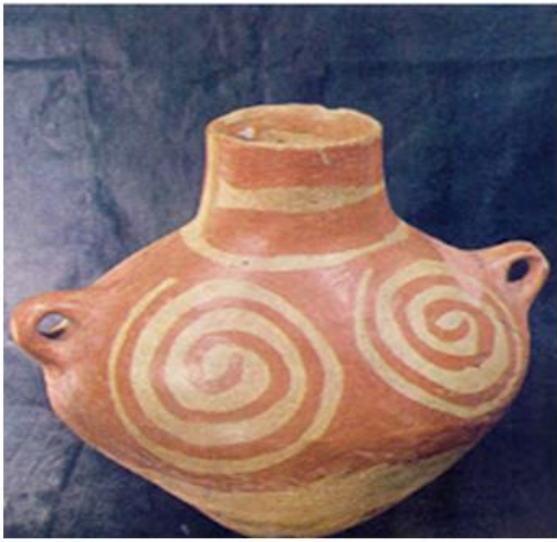

Görsel 3: Çatalhöyük’te bulunan çanak ve çömleklerde geometrik formlara rastlanmıștır. (Kalkolitik döneme MÖ 5500-5000)
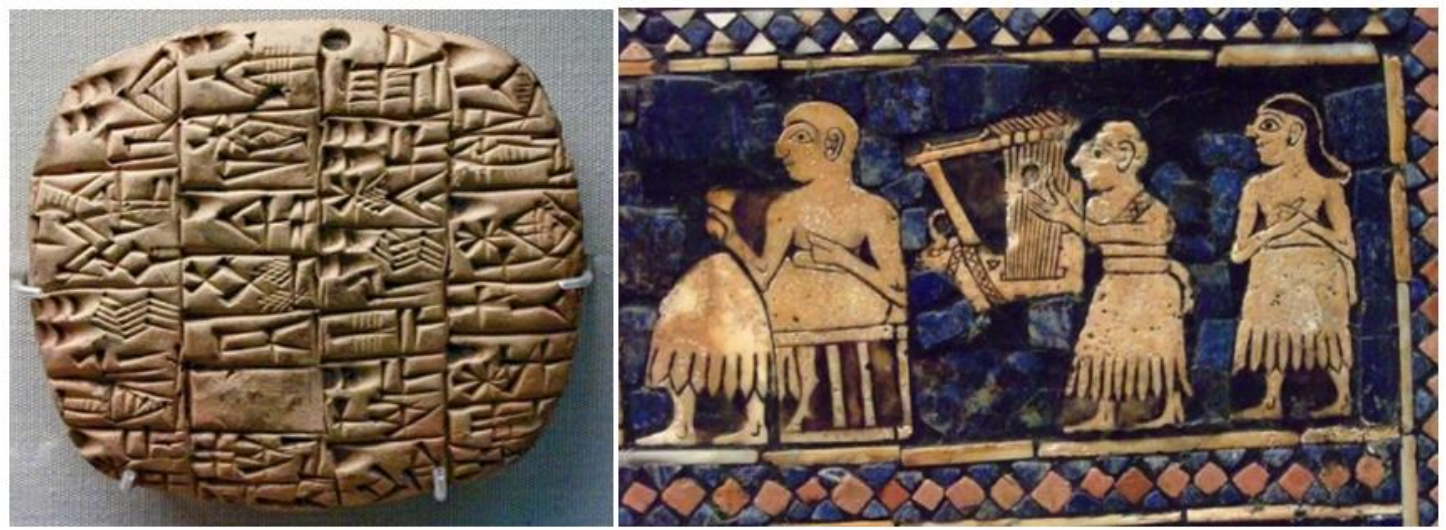

Görsel 4: Sümer çivi yazısı ve Mezopotamya(Sümer resim sanatı MÖ.4000-2000)

Görsel 4'de Sümer çivi yazısı, resimli bir yazıdır. Bu tablette çizgi, üçgen, dörtgen, açı, yıldızı andıran geometrik formlar olduğu görülmektedir. Bu tabletlerde ayrıca simetri ve düzene de önem verildiği görülür. Çiviyle yazıldığı için düz çizgilerle formlar oluşturulmuştur. Görsel 4 ve Görsel 5‘de görüldüğü gibi kabartma resimlerde(rölyef) figürlerle birlikte geometrik formlarda kullanıldığı görülmektedir.

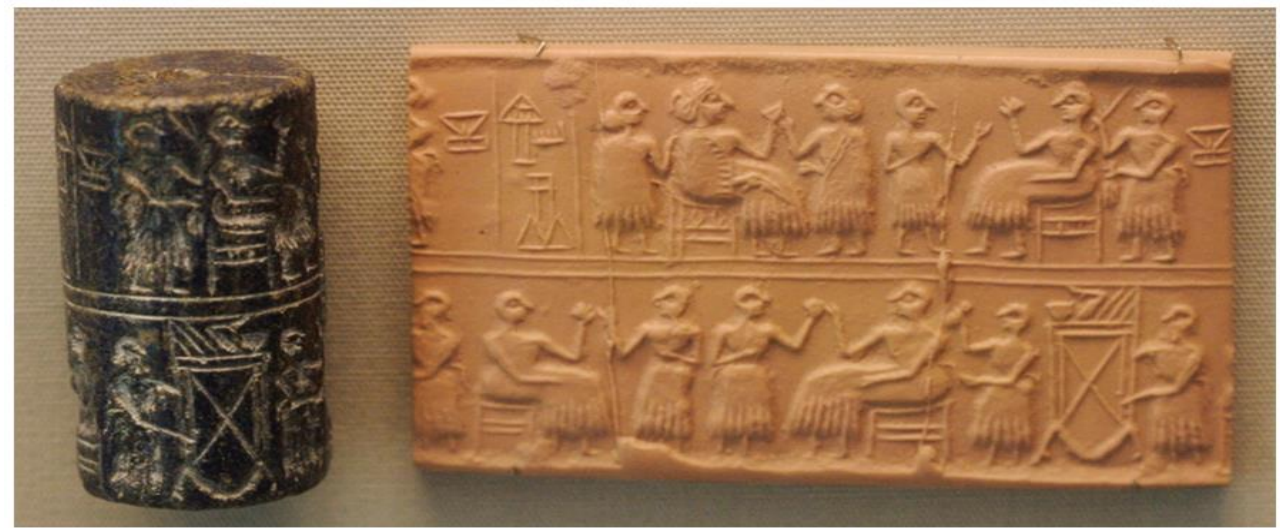

Görsel 5:Mezopotamya Sanat1, Uruk Dönemi silindir mühür ve tablet, MÖ 2600

40 | P a g e

www.iiste.org 

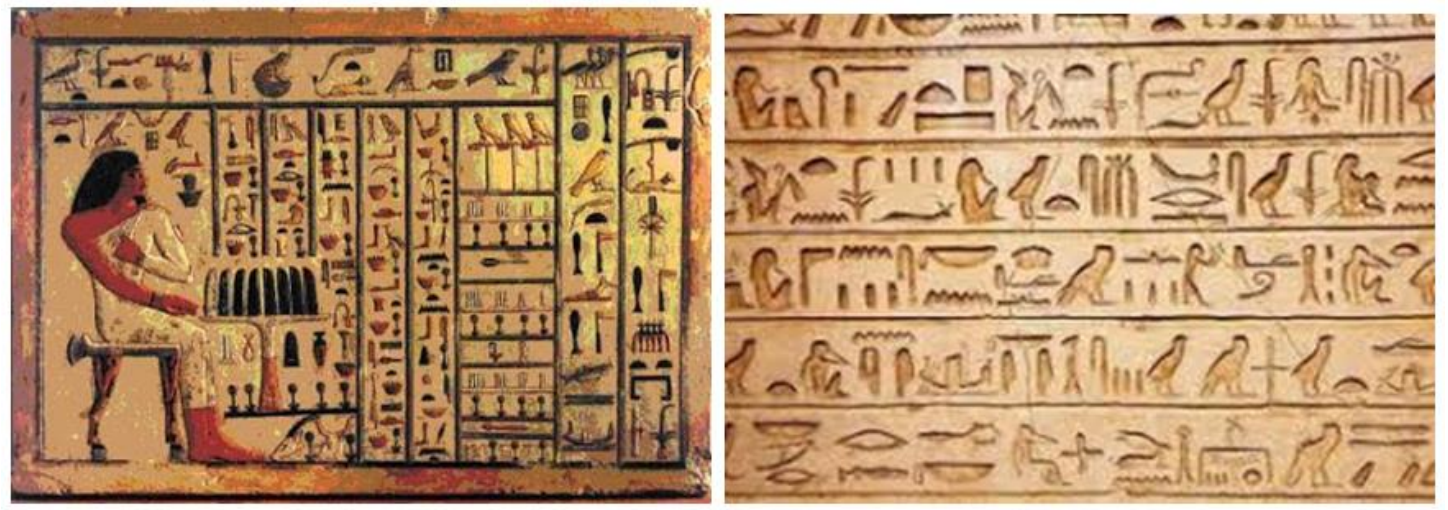

Görsel 6: Misır resimleri ve hiyeroglifleri

Mısır hiyerogliflerinde ${ }^{*}$ de nokta, çizgi, çember, dörtgen ve çeşitli simgesel formlar yüzeye oyularak gösterilmiştir. (Görsel 6) Mısır yazısı resimli bir yazıdır. Resimde, yazı, resmin fonunu(mekânını) oluşturmaktadır. Resimde dikey-yatay çizgi formuyla geometrik bir tablo ve içerisinde sembol, şekil, hayvan figürleri yer almaktadır. Form durumunda betimlenen figür yüzeysel ve şematiktir. Bu tablo formu matematikte matris ve modern matematik tablosu olarak günümüzde de kullanılmaktadır. Anadolu'da kurulan uygarlıklarda da geometrik formlarının kullanıldığ görülmektedir.(Görsel 7, Görsel 8)

(Görsel 9)Frigler seramiklerini genellikle geometrik motiflerle bezenmiştir. Bunlar zig zag damalı, üçgen yada karelerdir. Bazı örneklerde ise panolara bölünmüş ve bu panoların içleri hayvan motifleri ile doldurulmuştur. Frig kültüründe firınlamadan önce kapların üzerine desenleri basmıştır. http://www.megep.meb.gov.tr/mte_program_modul/moduller_pdf/Antik\%20Form\%20Tasar\%C4\%B1 $\mathrm{m} \% \mathrm{C} 4 \% \mathrm{~B} 1 . \mathrm{pdf}$

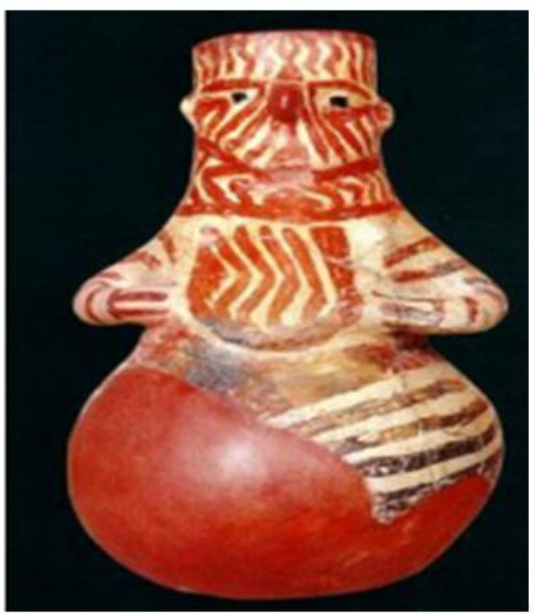

Görsel 7:Pişmiş Toprak .Hacılar (M.Ö 7500-3000) Neolitik Çağ (M.Ö $8.000-$ 5.500)

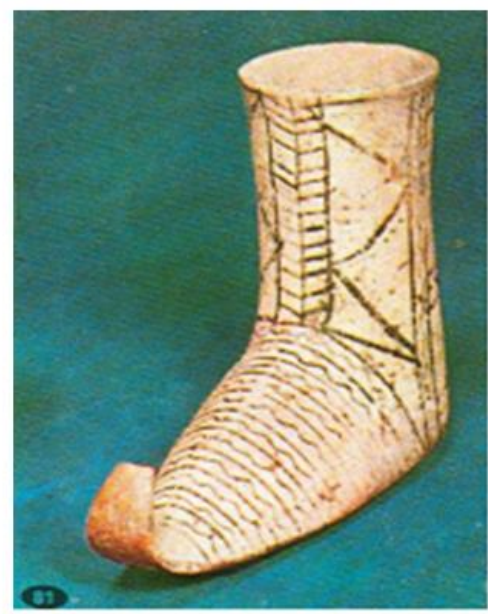

Görsel 8: Riton içki kabı, (çarık şeklinde) Asur Ticaret Kolonileri Çağı (M.Ö.1950-1750) Kültepe

\footnotetext{
* Hiyeroglif: Eski Mısırlıların kullandığı yazı türü. Betimlenen bir resim ile anlatılmak istenen bir kelimenin gösterdiği yazı, resim yazı(Komisyon,2010)
}

41 I P a g e

www.iiste.org 

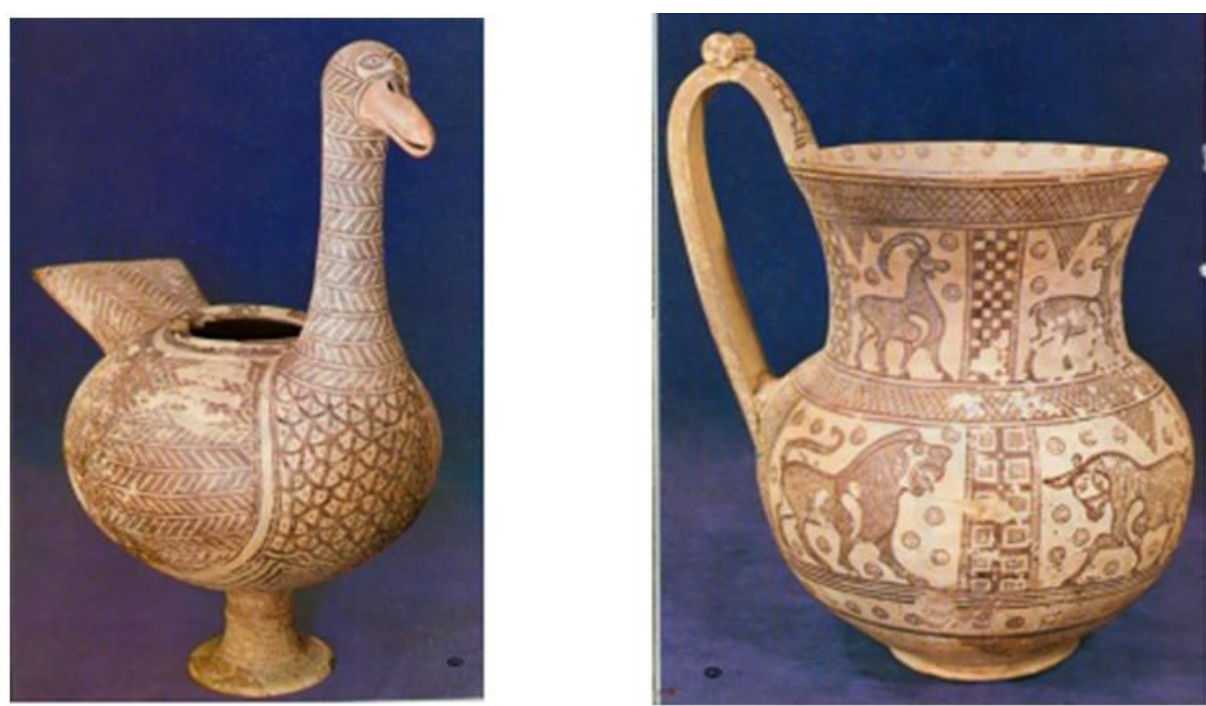

Görsel 9:Frig dönemi(M.Ö.1200-700)

http://www.megep.meb.gov.tr/mte_program_modul/moduller_pdf/Antik\%20Form\%20Tasar\%C4\%B1 m\%C4\%B1.pdf

Yunan vazo resim sanatında, matematiksel görseller vazgeçilmez biçimleridir.( MÖ. 11. - 3. yy.). (Görsel 10.) İkinci vazoda figür de kullanılmıştır. Figürler şematiktir.
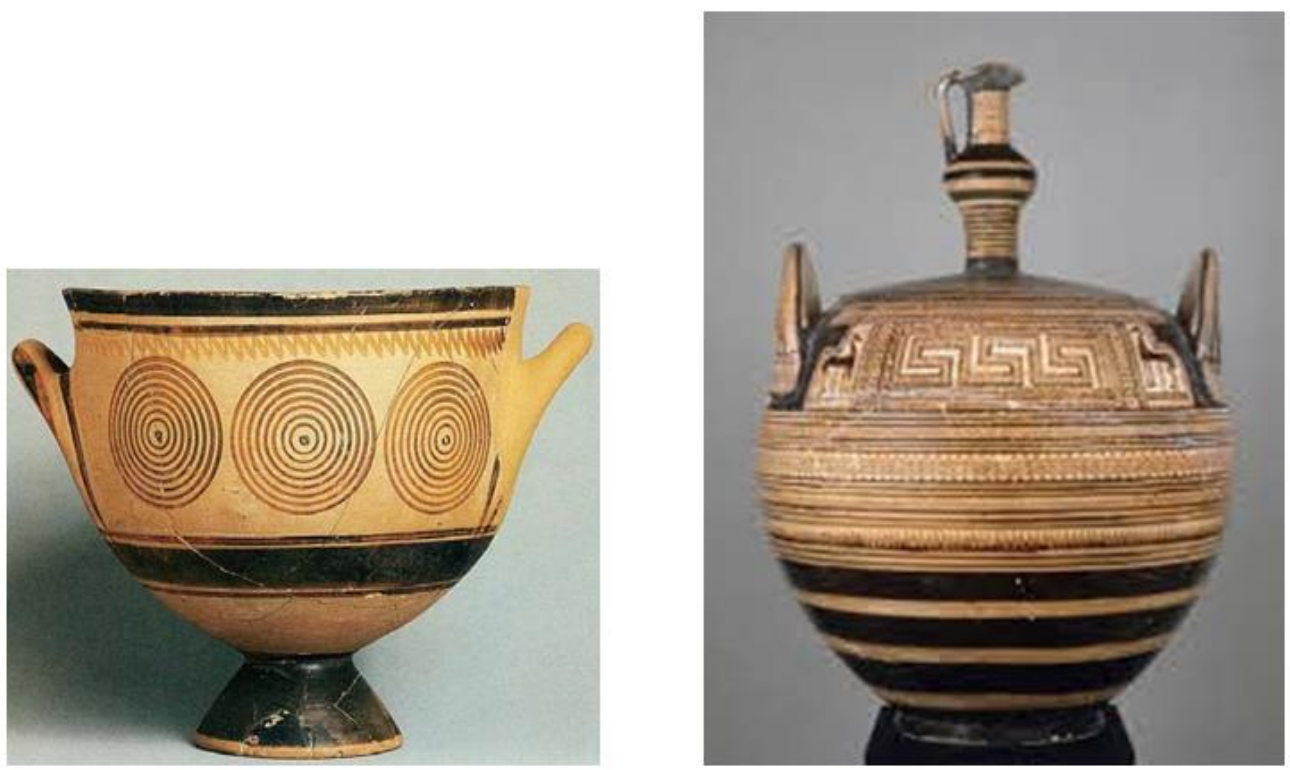

Görsel 10 : Yunan geometrik form içeren vazo(Proto Geometrik Dönem ve Basit hayvan figürlü geometrik vazo, Geometrik Dönem, Louvre Müzesi

https://www.sosyalarastirmalar.com/cilt11/sayi59_pdf/3sanat_sanattarihi_arkeoloji_mimari/yuksel_ism et.pdf 


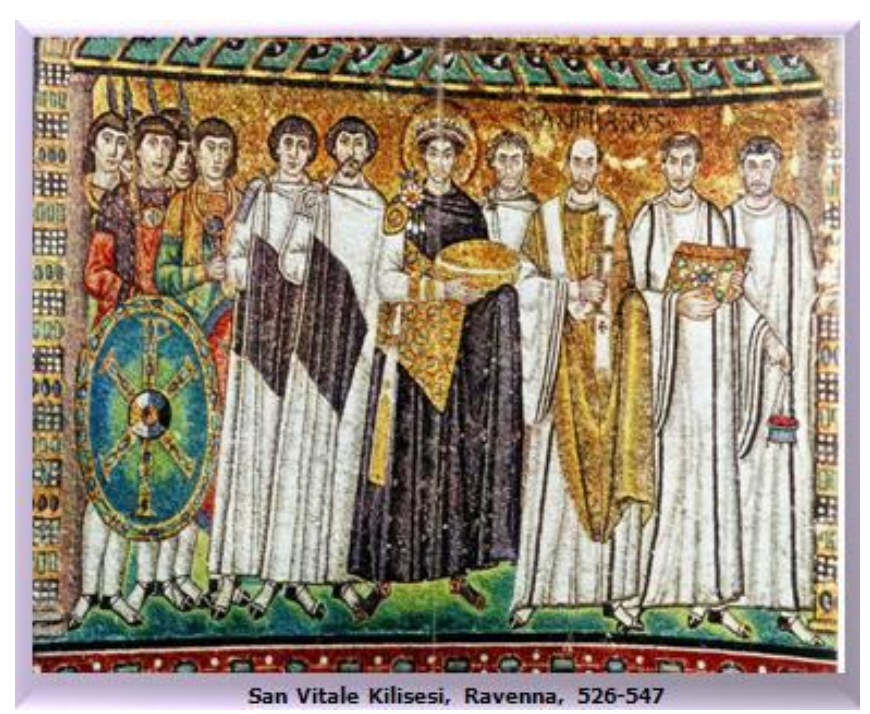

Görsel 11: San Vitale Kilisesi Ravenna,526547 Bizans mozaik sanatı

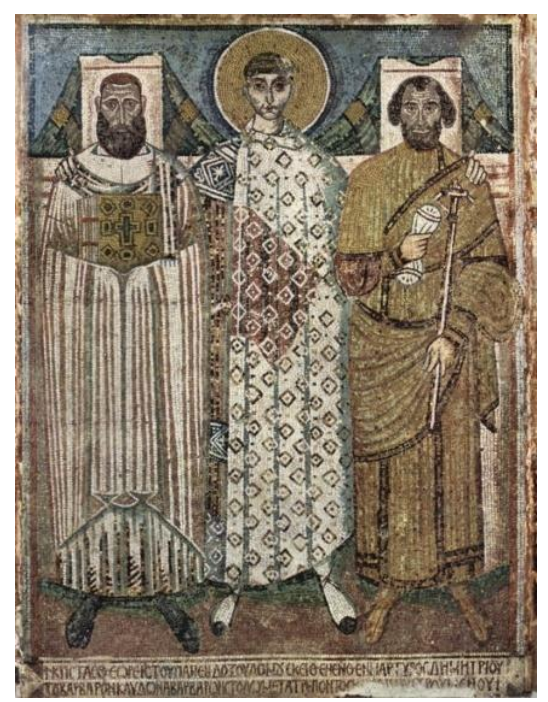

Görsel 12: Selanik'te bir kiliseden mozaikler. 7.- 8. yy.

Gordon Johnston, Roma Sanatının (M.Ö.146-M.S.400) Yunan sanatından etkilendiği ve pek çok resimde matematiksel görsellerle başarılı fresk ve mozaik ${ }^{*}$ örnekleri bıraktıklarını söyler. (Johnston,1993) Mozaik, mimaride ve resimde kullanılan bir tekniktir. Mozaik parçalarının her biri matematiğin formlarından olan kare, dörtgen ve üçgen prizmalardan oluşmaktadır. (Görsel 11-12.) Birinci resimde figürlerin bastığı zeminde perspektifin varlığı gözlemlenmektedir. Bizans Sanatı, M.S.400 başlamış, Yunanistan ve Rusya'da 17.yy ve daha sonrasına kadar devam etmiştir. Bizans resmi; fresk, mozaik ve İkon (dinsel pano) şeklindedir. (Johnston,1993) Bizans resim sanatında çeşitli geometrik formlar, Romen rakamları, sembol ve yazı gibi figür dışı oluşumlar yer almaktadır. (Görsel 7.-8..) Bizans resmi şematikliğini Doğu üslubunda, optik anlayışı da Helenistik üslupta(Yunan ve Roma Sanatı etkisiyle oluşan) almıştır.( Tansuğ, 2006)

Rönesans resim sanatında da matematiğin görselleri yer almıştır. Albrecht Dürer'in Görsel 13.'deki resminde; pergel, küre, çember, ucu kesik bir prizma gibi geometrik formlar ile içinde rakamlar bulunan sihirli kare* yer almaktadır. Bu sihirli kare tablosunda Albert Dürer'in annesinin ölüm y1l olan 1514 sayısı yer almaktadır. Sembolik ifadeler için de matematikten yararlanılmıştır. Sihirli karelerin özelliği, her satır, sütun ve köşegenlerinin toplamının aynı sayıyı vermesidir.

Görsel 14.'de ise, Pisagor'un elinde bir piramit, masanın üstünde bir pergel, papirüs Pisagor teoreminin geometriksel ifadesi görülmektedir. Fonda gökyüzüne doğru bir üçgen sembolik anlamda kullanılmıştır. Pisagor'un solunda müzik nesneleri, masanın üstünde küre ve silindir formları görülmektedir. Bu resimde matematiğin müzikle ilişkisi de anlatılmaktadır. Pisagor üçgeninde, belli bir düzen içinde eşkenar üçgenler sonsuza kadar çoğaltılabilir. Bu matematikte ve resim sanatında fraktal kavramı ile çakışmaktadır.

\footnotetext{
${ }^{*}$ Küçük, birbirinden farklı, üç boyutlu parçaları bir yüzey üzerinde yan yana getirerek resim oluşturma tekniğine ve ortaya çıkan esere de mozaik denir.
}

*Sihirli kareler, M.Ö. 2200 yıllarından beri bilinmektedir. Tarihsel süreç içinde Araplar, Çin, Antik Yunan, Hindistan ve
Japonya'da düzenlenmiştir. 19. yüzyılın sonlarında matematikçiler sihirli kareleri olasılı ve analiz problemlerinde uygulamaya başlamışlardır.

43 | P a g e

www.iiste.org 

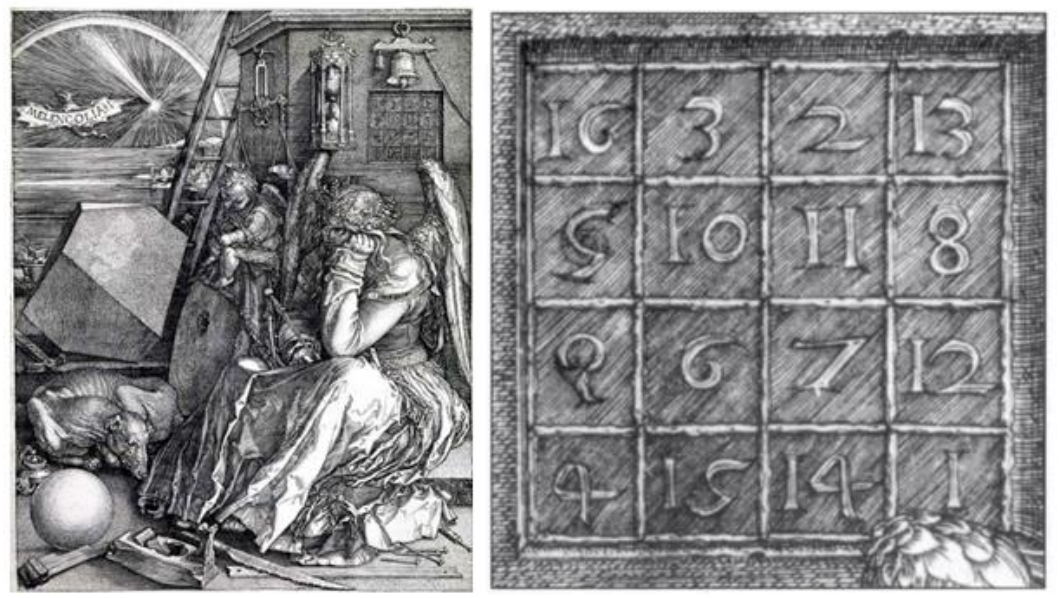

$\begin{array}{llll}16 & 03 & 02 & 13 \\ 05 & 10 & 11 & 08 \\ 09 & 06 & 07 & 12 \\ 04 & 15 & 14 & 01\end{array}$

Görsel 13: Albrecht Dürer,1514, gravür, 24x18,8cm ve sihirli karenin ayrıntıs1 (Hatice Karadoğan'ın tezinden)

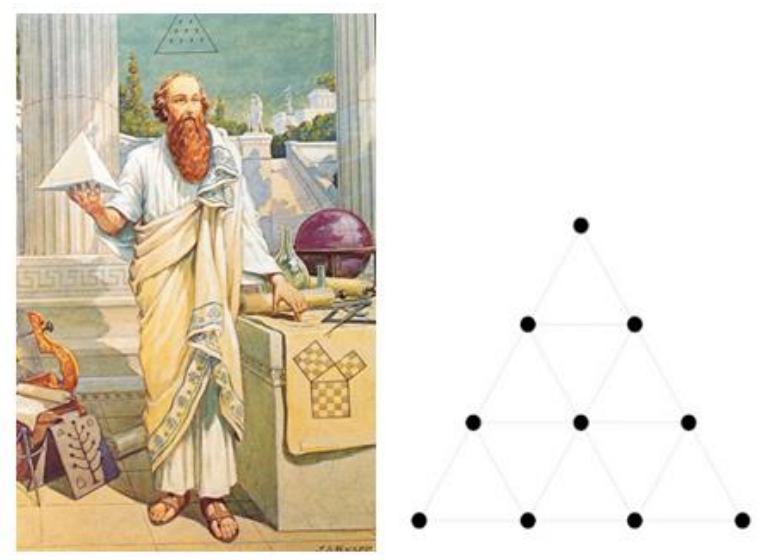

Görsel 14: Pisagor Kendi Okulunda adlı resim ve Pisagor üçgeni(Hatice Karadoğan'1n tezinden)
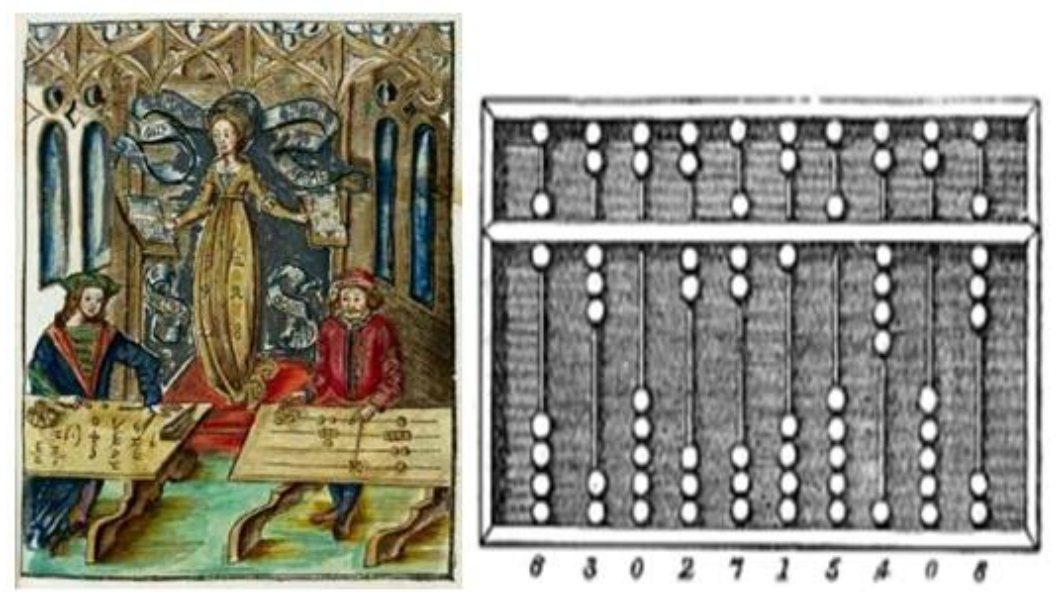

Görsel 15: Grogor Reisch, Bayan Aritmetik(Madame Arithmatica),1508, Abaküs adlı hesap tablosu (Hatice Karadoğan'ın tezinden) 
Görsel 15.'de iki öğrencinin matematik işlemlerini, abaküs* yardımıyla çözmeye uğraşmaları betimlenmiştir. Figürün elbisesinde ve masa üzerindeki çalışmada matematik işaretleri ve geometrik formlar mevcuttur.

Rönesans'tan sonra modern sanat döneminde matematiğin görselleri daha yoğun olarak görülmektedir. Kübizm, Soyut, Op-Art, Mathart, Kavramsal, Konstrüktivizmde matematiksel görseller ana eleman yani form olarak birçok sanatçı tarafında kullanılmıştır. Geometrik formları kullanan sanatçılar; Cézanne, Picasso, Braque, Juan Gris, Delanuay, Léger, Lyonel Feininger, Kandinsky, Mondrian, Van Doesburg, Malevich, Frank Stella, Sol Le Witt vb. ile matematiksel sembolleri kullanan sanatçılar Klee, Jasper Johns, Antoni Tapies, Bradley Tomlin, Pollock, Franz Kline, Mark Tobey, Gérard Schneider vb. sayabilir.

Van Gogh Görsel 16'de geometrik formla mekân resmetmiştir. Düşünen ve hareket halinde figürlerle dikey formdadır. Pencereden giren 1 şık ve dolayısıyla oluşan gölge rengin tonlarıyla verilmiştir. Mavi ve turuncu zit renk armonisi kullanılmıştır. Empresyonizmde renk en önemli resim öğesi olarak sanatta yerini almış ve 1şı̆̆ın geliş açısının gölge oluşumuna etkisi keşfedilmiş ve bu da matematiksel bilginin önemini göstermektedir.

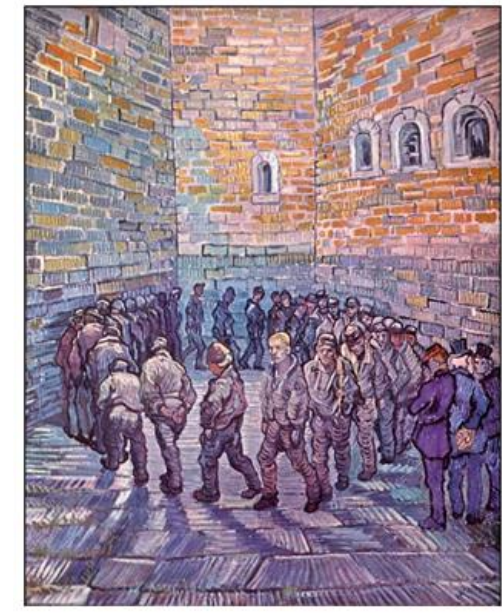

Görsel 16: Van Gogh, Volta, 1890, 80x64cm, T.ü.y.b., Pushkin Müzesi /Moskova-Rusya

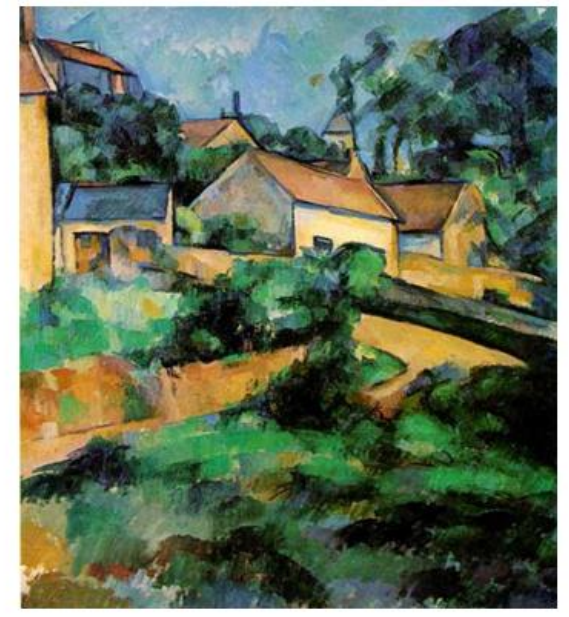

Görsel 17: Paul Cézanne, Mont Geroul'da Sokak, 1899,65 x 52 cm, Yağlıboya, Post Empresyonist, Whitney Museum of American Art New York

İlk defa mekânı geometrik üç boyutlu formlara indirgeyip resmeden sanatçı Cézanne'dir. (Görsel 17.). $\mathrm{Bu}$ manzara resminde ev küp, çatı piramit, ağaç ve çalılar geometrik lekelerle renk aracılığıyla hacimsellik verilerek betimlenmiştir. Doğal formlar soyutlanarak geometrik formlara dönüştürülmüştür. Derinlik yanılsaması ön arka formlarla sağlanmıştır.Tek kaçış noktalı perspektiften kaçınılmıştır. Kübizm'le de objeler geometrik formların parçaları halinde resmedilmiştir.( Görsel 18.19.) Bu biçimlemeler iki boyutlu geometrik formlar şeklindedir. Mekân önemsenmemiştir. Üçüncü boyutu, tuvalin üzerine perspektif olmadan getirebilmesi akımın temel özelliğidir. (Mirza,2009) Kübizm'le ilk defa figürlerin görünmeyen tarafları aynı düzlemde iki boyutlu olarak resmedilmiştir. Bir nesnein etrafinda dolaşıyormuş gibi zaman boyutunu da resme katmışlar ve dört boyut iki boyutlu yüzeyde resmedilmektedir. Picasso ve Braque'nin resimlerinde figürler geometrik formlar şeklinde parçalanarak mozaik form şeklinde ifade edilmiştir.

\footnotetext{
*Abaküs, Brittanica Ansiklopedisi'nde abaküs, Antik çağlardan beri kullanılan hesap aygıtı M.Ö.2400 Çin'de geliştirilmişstir. Bu dönemlerde bu tür aygıtlarla matematik hesapları yapılmışttr.
}

45 I P a g e

www.iiste.org 


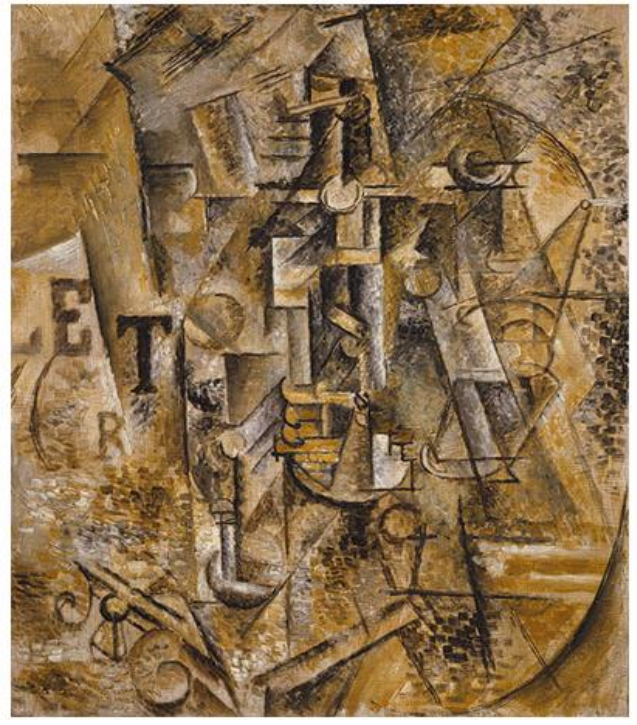

Görsel 18: Picasso, 1911, Still Life with a Bottle of Rum, oil on canvas, 61.3 $50.5 \mathrm{~cm}$, Metropolitan Museum of Art, New York

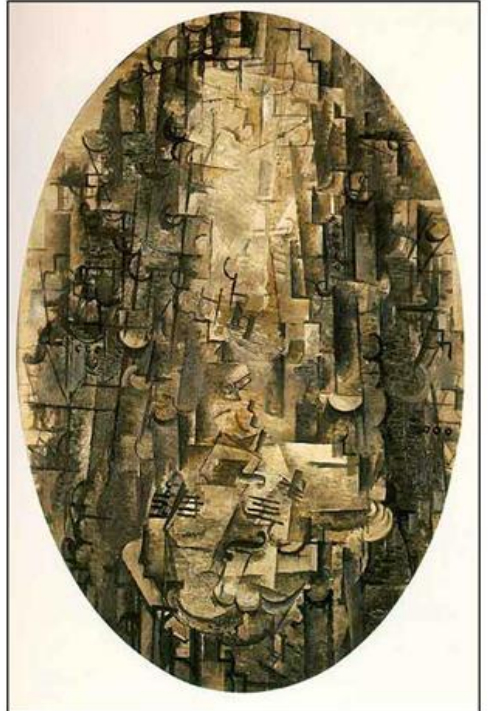

Görsel 19: Braque, Kemanlı Adam, 1912 , T.ü,y.b., 100 x $73 \mathrm{~cm}$, E.G. Buhrie Coll. Vakfi/ Zürih - İsviçre

Soyut sanat Kandinsky'le başlamıştır. Kandinsky'nin resimlerinde ise geometrik formlar renkler aracılığıyla simgesel motiflere dönüşmüştür. Görsel 20.'de geometrik formlarla bezediği resimlerinde, dama formu, kare, üçgen, büyük-küçük dairesel formlar, yön belirten üçgen formlar, çizgiler vb. yer almıştır. Bazı dörtgen formlar uzayda sonsuzluğa gidiyor gibi resimlenmiştir. Max Bill(Görsel 21.)de üçgen formu ile bir spiral formu oluşturmuştur. Mondrian (Görsel 24 ), bir alanın veya biçimin özünü yatay ve dikey çizgilerin oluşturduğunu savunmuştur. Resimleri ana renklerle doldurulmuş siyah kalın konturlu dikdörtgenlerden oluşturur. Resimleri, Tangram* oyunda benzerlik gösterir.( Görsel 23.) Tangram oyununda esinlenen diğer bir ressam Van Doesburg’dır. (Görsel 23.)

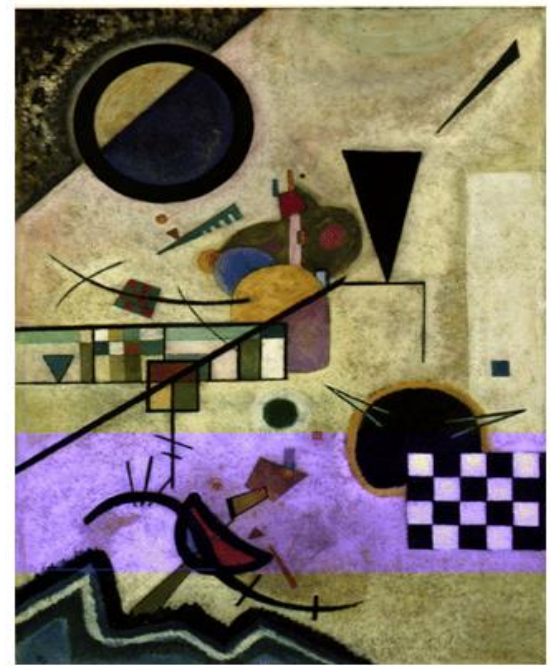

Görsel 20: Wassily Kandinsky 1924, Contrasting Sounds, Geometric abstraction, Oil on cardboard, $70.0 \times$ $49.5 \mathrm{~cm}$

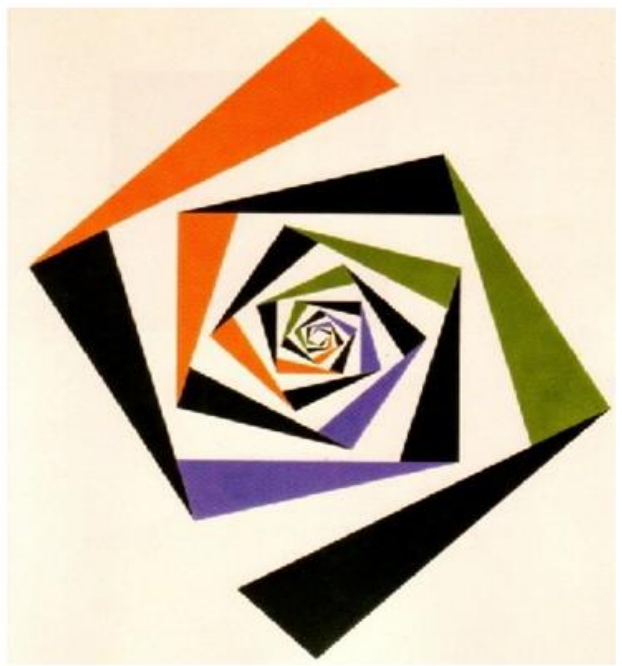

Görsel 21: Max Bill, Construction in 19 Squares, 1941, gouache on board, $102 \times 72 \mathrm{~cm}$

\footnotetext{
* Tangram yedi adet geometrik formun bir araya getirilmesi sonucu yaratılan bir zekâ oyunudur. Çin'de geliştirilen bu oyunun ortaya çıkışı çok eski tarihlerde olmuştur.
}

46 I P a g e

www.iiste.org 


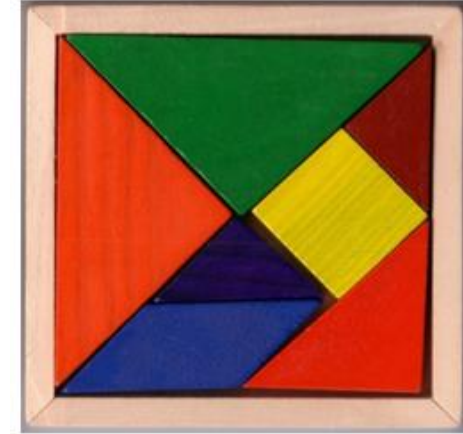

Görsel 22: Tangram oyunundaki geometrik formlar (Hatice Karadoğan'in tezinden)

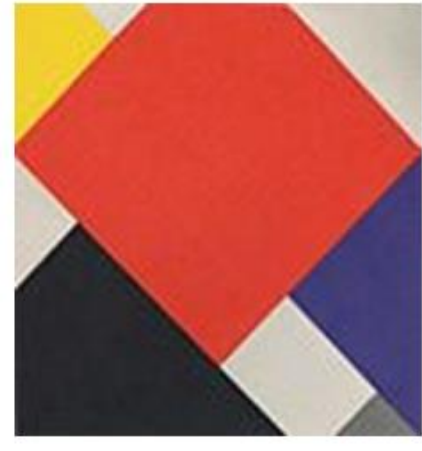

Görsel 23: Theo van Doesburg, Karşı Kompozisyon V, 1924, T.ü.y.b., 100 x $100 \mathrm{~cm}$, Özel Koleksiyon (Hatice Karadoğan'1n tezinden)

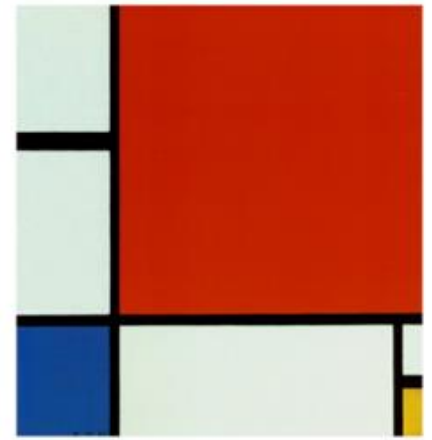

Görsel 24: Mondrian, Kırmiz1 Mavi ve Sar1 Kompozisyon II, 1930 (Hatice Karadoğan'ın tezinden)

Geometrik formları kullanan diğer bir sanatçı süprematist Malevich’tir. Soyut çalışmalarında, kare, daire ve haç formu(artı işareti), genelde siyah beyaz zıtlığı ile resimlemiştir. (Görsel 25')de geometrik formları en sade biçimde kullanmıştır. Süpramatizm soyut geometri resim anlayışıdır. Maleviç'in 1913'ten sonra resimlerini obje ve figürden uzaklaştırıp saf geometrik formlarla ifade etme şekline denir. Geometrik formları kullanan diğer bir sanatçı da Frank Stella’dır. Resimlerinde, üçgen, daire dilimleri, koni vb. geometrik formları kullanmıştır. Ayrıca bu formları tek başına veya birkaçını bir arada kullandığı tuval formları mevcuttur. ( Görsel 26.)Bu tabloda kare ve çeyrek daire tablolarını birleştirerek bir resim oluşturmuştur.

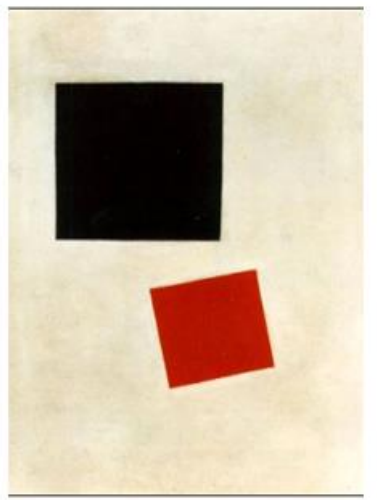

Görsel 25: Malevich Kasimir, Siyah ve Kırmızı Kare,

1915,T.ü.y.b., 71,4 x 44,4 cm, Modern Sanatlar Müzesi / New York - Amerika

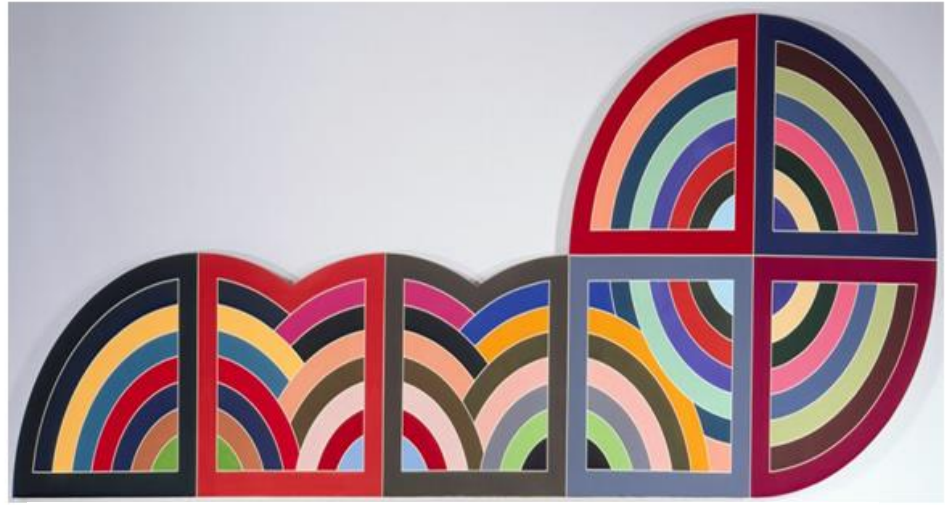

Görsel 26: Frank Stella, ,1970, Resim, 304.8 x 762 cm

Herhangi bir resim akımı içinde yer almayan Paul Klee, dışavurumcu soyutlamaları oldukça kişisel ve simgeci bir biçimde tuvale aktararak sanat tarihinin en özellikli yaratıcılarından biri haline gelmiştir. (Klee,2006) Klee, matematiğin sembolleri ile geometrinin formlarını hiyerogliflerin etkisi ile resim yüzeyinde buluşturmuştur. Görsel 27'de Sıfır formu, Pi sayısının görseli vb çeşitli şematik figürler yer almıştır. 


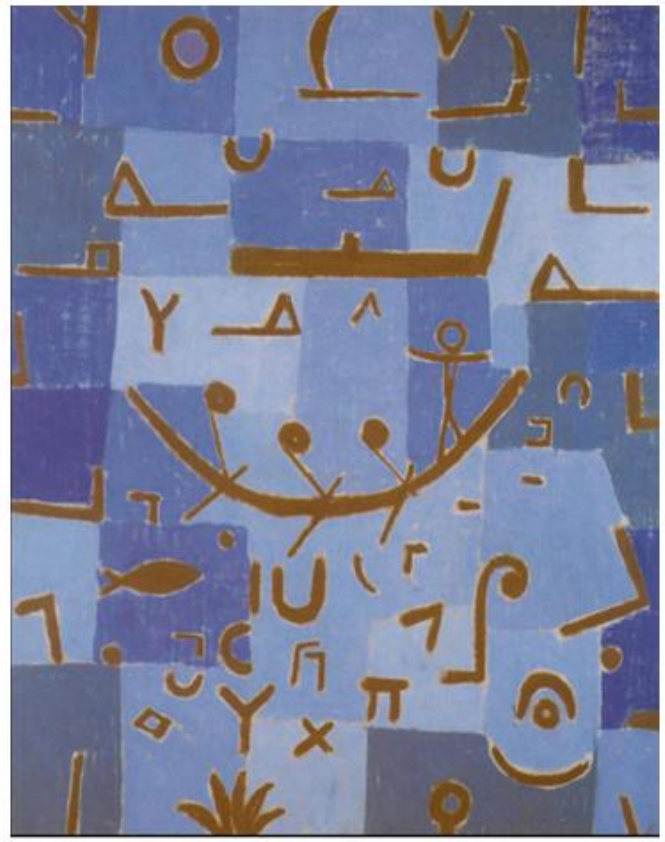

Görsel 27: Paul Klee, Nil Efsanelerinden, 1937, Çuval bezi üzerine pastel, 69x61 cm, Kunstmuseum / Berne - İsviçre

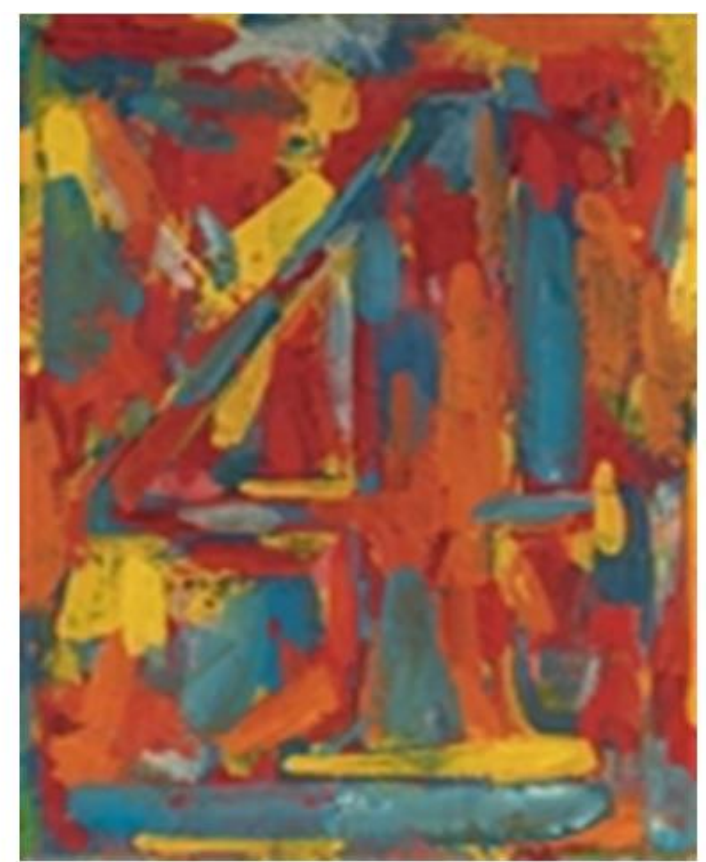

Görsel 28: Jasper Johns, Renkli 4 rakamı, 1959, tuval üzerine yağ, sicak balmumu,kolaj, 51.4 x $39.4 \mathrm{~cm}$

Jasper Johns, (Görsel 28) 4 rakamını renk armonisi içinde resmetmiştir. Antoni Tapies’in resimlerinde matematiğin işaret ve sembolleri duvar gibi doğal zemini andıran tuvaller üzerinde betimlemiştir. Görsel 29'deki resimlerine bakıldığında resimlerinde, X işareti, + toplama işlemi, çeşitli sayısı ve matematik sembollerini kullanmıştır.( Görsel 30)Matematiğin işaret ve formlarını kullanan diğer bir sanatçı Pollock'tur.

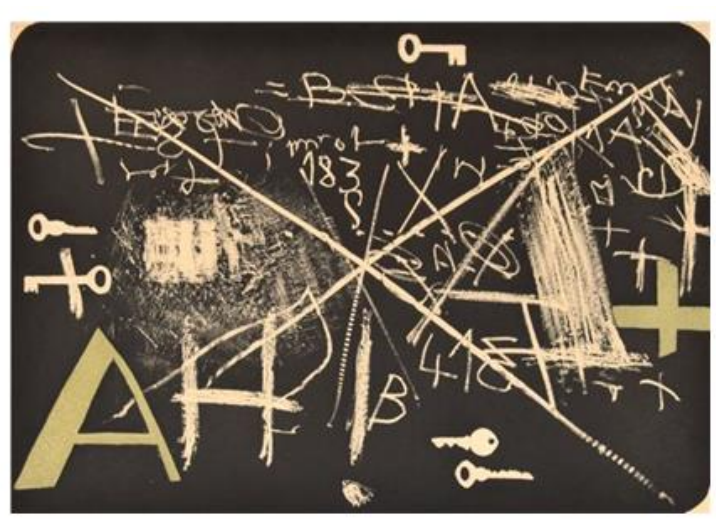

Görsel 29: Antoni Tapies, Antoni Tapies, "Esperit Catalia II" Etching, Signed Edition, 1974, etching with embossing on Guarro paper, 19"hx 25"w

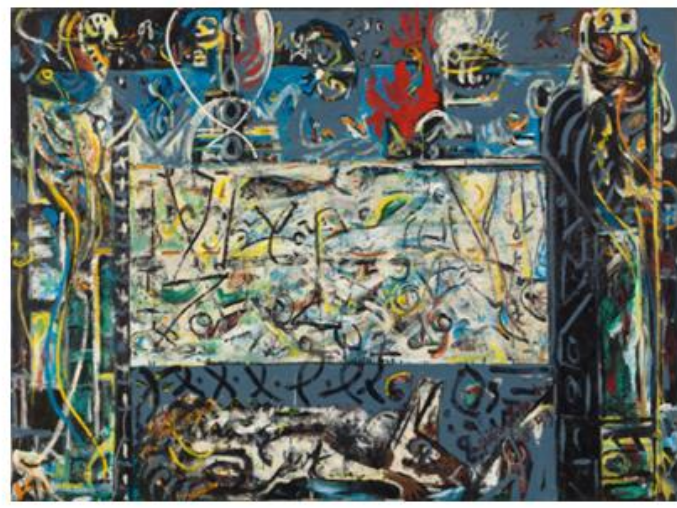

Görsel 30: Jackson Pollock, Guardians of the Secret, 1943, Oil on canvas, $122.9 \times 191.5 \mathrm{~cm}$ San Francisco Museum of Modern Art (SFMOMA) 


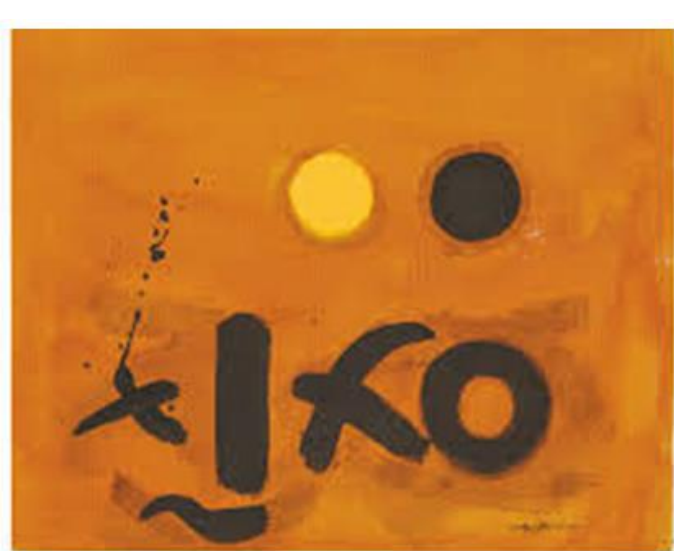

Görsel 31: Adolph Gottlieb,

Untitled, 1965, acrylic and ink on paper, $51.1 \times 66.4 \mathrm{~cm}$.

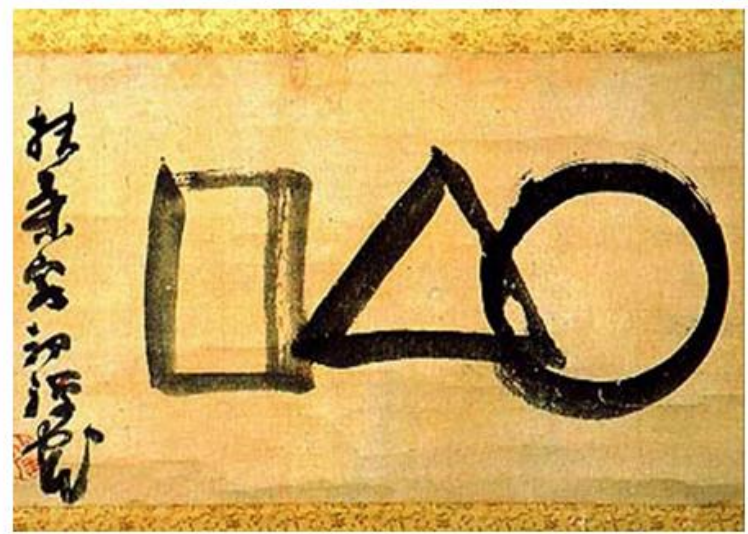

Görsel 32: Sengai Gibon, Çember, Üçgen ve Kare(Evren), 19.yy., K.ü.m., 28.4 x $48.1 \mathrm{~cm}$, Idemitsu Sanat Müzesi, Tokyo

(Görsel 27)Üçgen tüm formların başlangıcı, kare iki üçgenden oluşur. Her üçgen sonsuz defa katlanarak küçük üçgenler oluşabilir. Bu ikiye katlama sonsuza sürer. Daire ise sonsuzu temsil eder. Bu üç form zen öğretisine göre evreni temsil ederler.

Adolph Gottlieb(Görsel 31.), Franz Kline. Mark Tobey, Antoni Tapies, Gérard Schneider, Cy Twombly, Sengai Gibon (Görsel 32.) vb. birçok sanatçı resimlerinde matematiğin rakam ve formlarını minimalist bir yaklamışla kullanmışlardır. Bu yaklaşım matematiğin sadeleştirme tavrı ile örtüşmektedir.

Halil Akdeniz de matematiksel bazı formları resimleriyle buluşturan bir sanatçıdır. Antik Grek, Anadolu Uygarlıklarına ait yazı, işaret ve simgeler(sembol) ile çağdaş dünyanın işaret ve simgelerini aynı resimsel yüzeylerde buluşturmaktadır. (Görsel 33.) Bu resimlerde altın oran simgesi olan Phi $(\phi)$, rakamlar, Anadolu uygarlığının birçok sembolik formlarını kullanılmıştır. Laszlo Moholy Nagy(Görse34.) geometrik form ve sayılarla çizgi formuyla geometrik bir düzenleme yapmıştır.

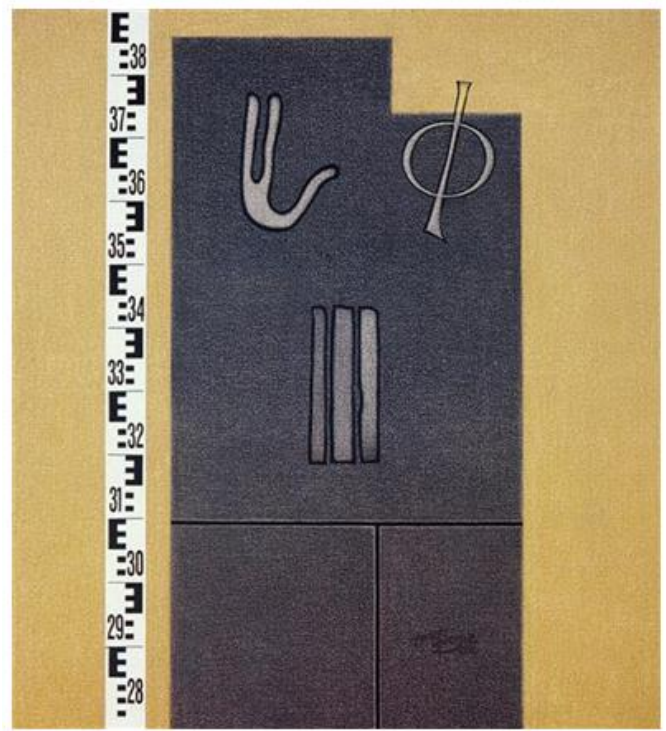

Görsel 33: Halil Akdeniz, 1994, Anadolu Uygarlıkları - Kültürlerarası, $115.00 \mathrm{x}$ $104.50 \mathrm{~cm}$.Tual üzerine akrilik, Özel Koleksiyon

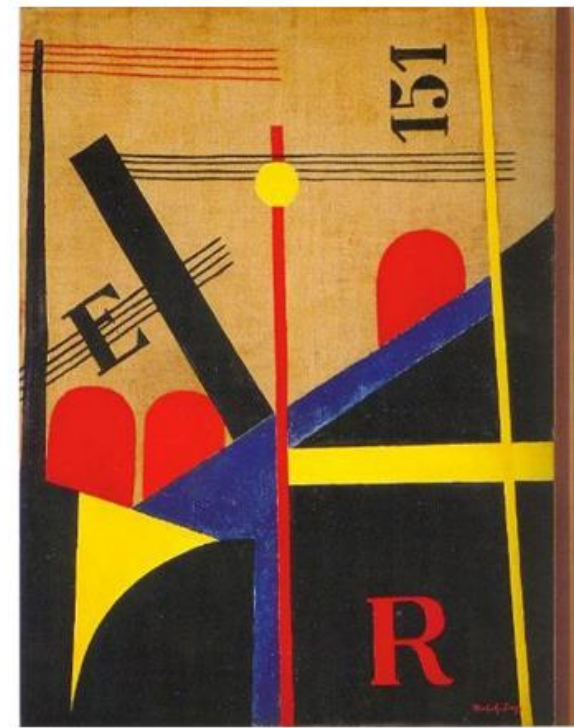

Görsel 34: Laszlo Moholy Nagy,1920,Large Railway Painting Oil On Canvas, 100 X 77 Cm, Museo Nacional Thyssen-Bornemisza, Madrid 
Sonuç olarak, 20.yy ve sonrasında soyut sanatla birlikte matematiğin görsellerini resimsel yüzeyde kullanan çok fazla sanatçı olmuştur.

\section{Resim Sanatında Matematiksel Bilgilerin Yeri}

Matematiğin görselleri dışında matematiğin bilgisi olarak perspektif yanılsama, altın oran, ölçü, denge, harmoni, kompozisyonun geometrik kurgusu olarak düşünülebilir.

Resim sanatında kompozisyonun geometrik kurgusu, figürlerin mekânı içinde kapladığı yer matematiksel bakış açısı gerektirir. Bu bakış açısıyla her dönem bazı sanatçılar yorumlarında bu yaklaşıma yakınlık duymuşlar ve resimlerinde uygulamışlardır. Resmin geometrik yapısını oluşturan, dikeyler, yataylar ve diyagonaller resim alanının iskeletini oluşturmaktadır. Tüm obje ve figürler bu iskelet üzerinde yer alır. Resim sanatında matematiğin bilgi olarak varlığını görmek mümkündür ve analiz edilebilmiştir. Karadağ'ın belirttiği gibi, bilim dalları kendi uzmanlık konularının analizi için matematikten yardım almaktadırlar. (Karadağ,2004) Adnan Turani'i "Resimde Geometri" adlı kitabında geometrik kurgunun önemine değinmiş ve resimleri geometrik kurgu içinde analiz etmiştir. Resmin kurgusu esnasındaki geometrik araştırma ve biçimlemelerin sanatçının zihinsel bir süreci olduğunu, ressamın çoğu zaman farkında olmadan geometrik yapıyı oluşturarak resmini tamamladığını söyler. (Turanî,1978) Resim her aşamasıyla bir akıl etkinliğidir, bu yönüyle de matematikle ortak paydada buluşur.( Sezgin,2011)

Rönesans öncesi resimler, bilimsel perspektiften uzak, ölçü kavramının tinsel amaçlara göre kullanıldığı Rönesans ise, matematiğin bilgi olarak resimde kullanıldığg bir dönemdir.

Misır resmi olan Görsel 35 incelendiğinde, bu resim Mısır'ın iki boyutlu şematik ve hiyeroglif resimlerindendir. Figürler önem sırasına göre resmedilmişlerdir. Buna "önem perspektifi” de denebilir. Büyük- küçük figürlerin kullanımı matematiğin ölçü kavramının bu dönemlerde de farkında olmalarındandır. Dikey ve yatay olarak bölmeler matematikteki Görsel 36'de görülen "Matris formunu" çağrıştırmaktadır. Matris matematiksel bir düzen ve ifadedir. Terazinin resimdeki yerine göre, asimetrik bir denge görülmekte ve bu da görsel dengeyi sağlamaktadır. Bu resmin geometrik kurgusunda dikey, yatay ve eğik yön doğrultuları gözlemlenmektedir.

Yunan vazo resmin geometrik kurgusu incelendiğinde yine yatay-dikey ve eğik çizgilerin varlı̆̆ görülebilir. Görsel 37'de hacimleme ve 1şık-gölge henüz bilinmediğinden kullanılmamıştır. M.Ö 510500 dolaylarında Yunan vazo resimlerinde Mısır üslubu dışına çıkılmış, figürler artık optik ${ }^{* *}$ olarak göründüğü gibi çizilmeye başlanmış ve ressamlar perspektif kısaltımını(rakursi) bulup karşıda görünen bir ayağın resmini çizmişlerdir.(Gombrich,1997) Böylece, Mısır sanatında, sanatçı bildiğini çizerken, Yunan sanatında sanatçı gördüğünü çizmeye başlamıştır. Rakursi ile derinlik yanılsaması sağlanmıştır.

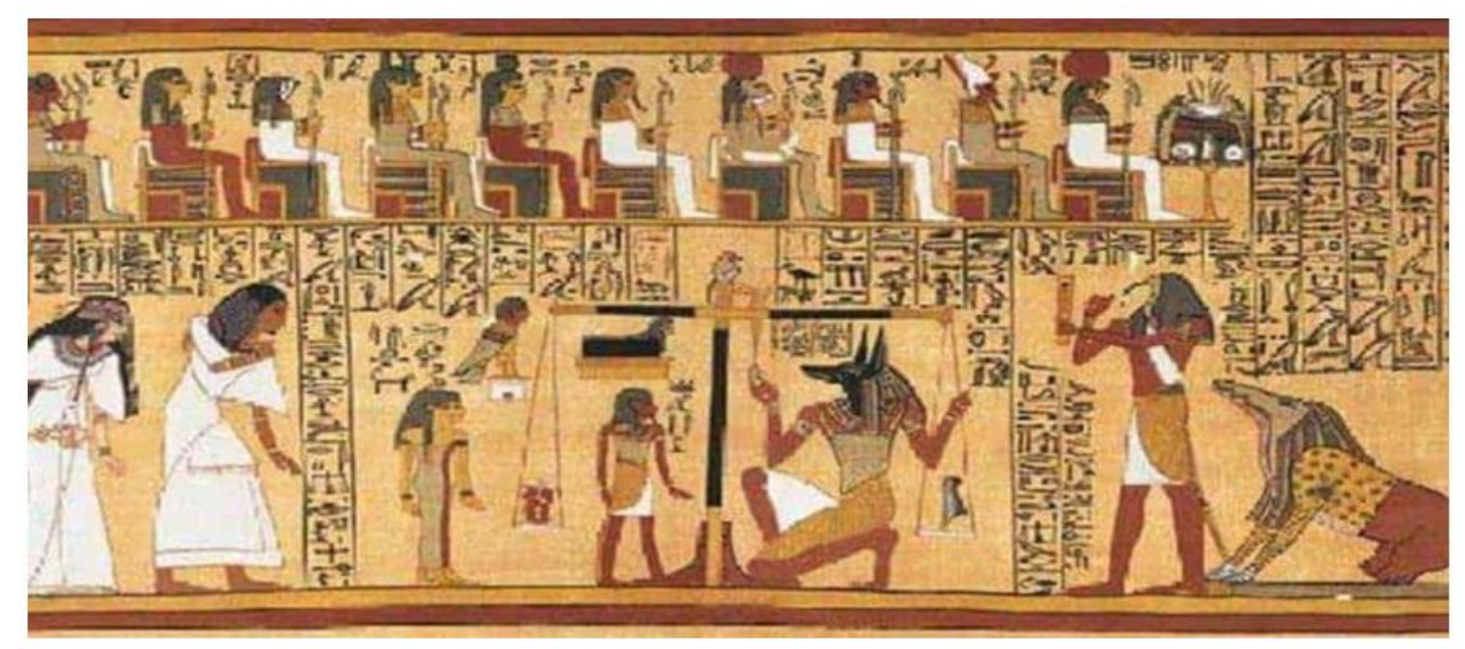

Görsel 35: Misır resmi

${ }^{* * *}$ Optik perspektif, gözle görünenin tasviri.

$\mathbf{5 0 |}$ | P g g e

www.iiste.org 


$$
\left[\begin{array}{llll}
a_{11} & a_{12} & a_{13} & a_{14} \\
a_{21} & a_{22} & a_{23} & a_{24} \\
a_{31} & a_{32} & a_{33} & a_{34} \\
a_{41} & a_{42} & a_{43} & a_{44}
\end{array}\right]\left[\begin{array}{l}
x_{1} \\
x_{2} \\
x_{3} \\
x_{4}
\end{array}\right]=\left[\begin{array}{l}
b_{1} \\
b_{2} \\
b_{3} \\
b_{4}
\end{array}\right] .
$$

Görsel 36: Matematiğin matris formu
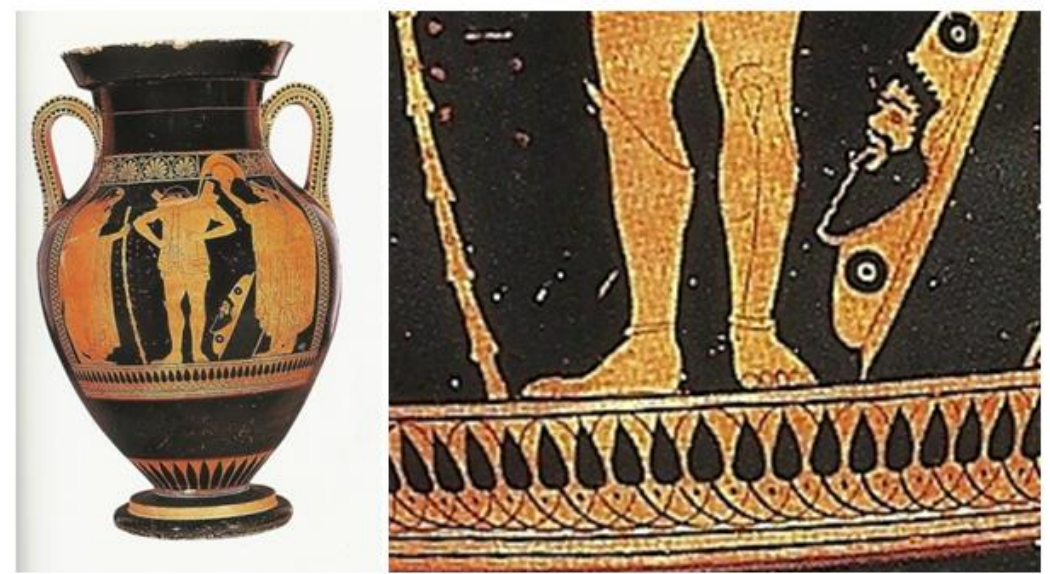

Görsel 37: Yunan Vazosu ve Ayak ayrıntısı, Savaşa Hazırlanan Genç, M.Ö.510-500 dolayları,” Euthymedes imzalı; yüksekliği 60cm; Staatliche Antikensammlungen und Glyptotkhek, Münih (Gombrich, Sanatın Öyküsü kitabından taratıldı.) (Hatice Karadoğan'ın tezinden)

Roma döneminde Görsel 38.'de görüldüğü gibi modle etme başlamıştır. Böylece hacim kavramı resimde yer almaya başlamış̧ır. Figürler altın dörtgen(kenar uzunlukları oranının $a / b=1,618$ yaklaşması) içinde, simetrik eksenleri dikkate alınarak resmedilmiştir. Simetrik bir kompozisyondur ve ortadaki figür önde ve ayakta rakursi uygulanmıştır.
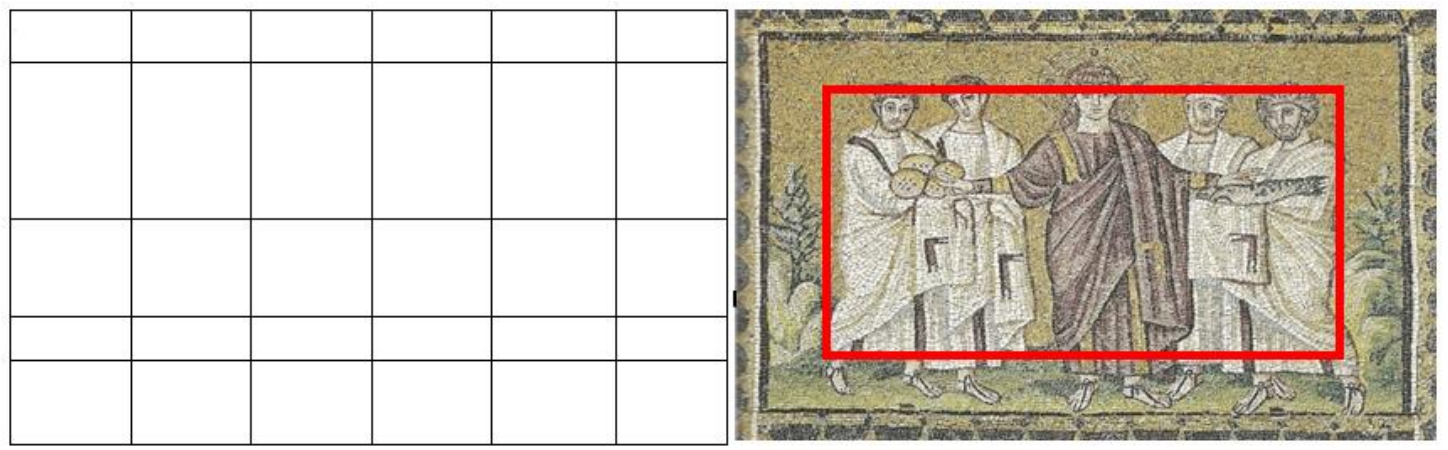

Görsel 38: M.S 520 dolayları, Ekmek ve Balık Mücizesi, Mozaik, S.Apollinare Nuovo Bazilikası, Ravenna, Roma Sanatı, (Gombrich,1997) ve geometrik kurgu analizi. (Hatice Karadoğan'ın tezinden)

Görsel 39'de üst bölümünde görülen mimari yapıda bilimsel perspektife benzeyen bir çizim söz konusudur. Geometrik formlarla bu perspektif desteklenmiştir. Sağda birinci figürün ayaklarında perspektif kısalıımı uygulanmıştır. Ön-arka figürlerle de derinlik verilmiştir. Çizgi formu ile kumaşa hacim verilmeye çalışılmıştır. Modle* etme henüz bilinmemektedir. Resmin geometrik analizi

* Modle: Ü̧̧ boyutlu nesneleri iki boyutlu bir yüzey üzerinde göstermek amacıyla ışılk ve gölgeyi kullanarak nesnelerin üzerindeki kabariklk ve girintileri resmetme teknigi.

51 I P a g e

www.iiste.org 
yapıldığında dik bir form olduğu görülmektedir. Soldaki figür başları; mimari yapıdaki kubbe, çatıların kiremitleri vb. tekrarlı formlarla ritim sağlanmıştır.

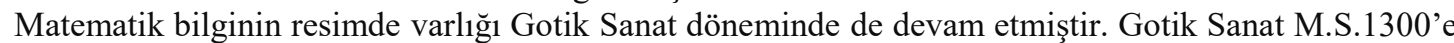
kadar sürmüştür. Bu dönemde Bizans sanatı örnek alınmış ve vitray, minyatür sanatlarına önem verilmiştir.(Görsel 40) Gotik dönemin figürlü resimlerinde perspektifi ilk kullanan Giotto Di Bondone(1266-1337) olmuştur. Görsel 40-41'de Mimari formlarda perspektif görülmektedir. Figürlerde hacimsellik önemsenmeye başlanmış, kumaşlarda 1şık- gölge ile figürlere hacimsellik verilmiştir. Gotik Dönem sanatçıları, Giotto, Cimabue,( Görsel 41) Jan van Eyck’dir.
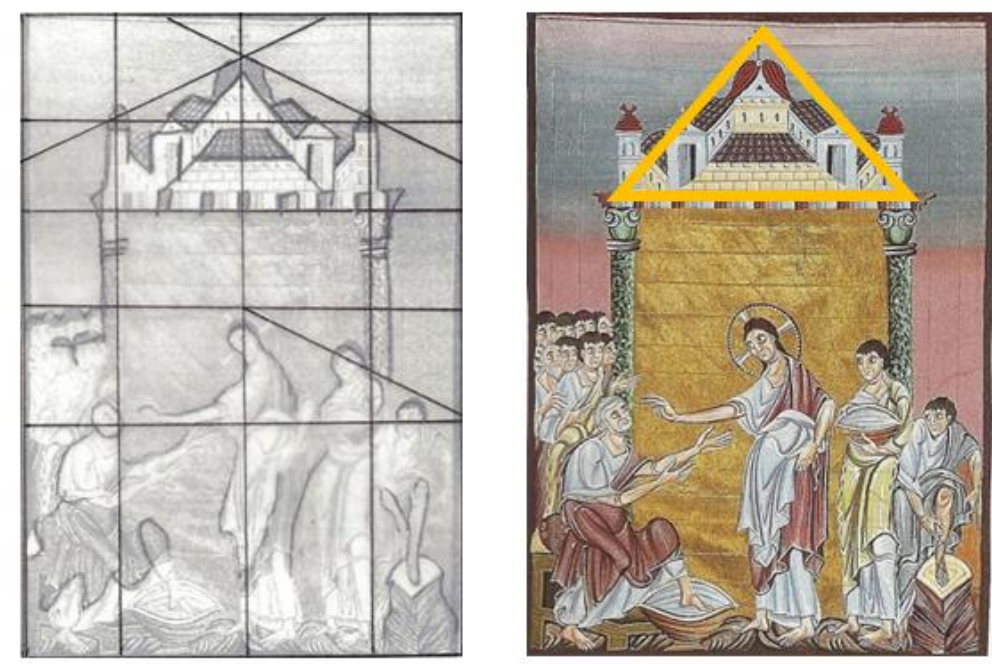

Görsel 39: İsa Havarilerin ayaklarını yıkıyor,1000 dolayları, III. Otto İncili’nden Bayerische Staatsbibliothek, Münih ve Resmin geometrik kurgusu(Hatice Karadoğan'1n tezinden)

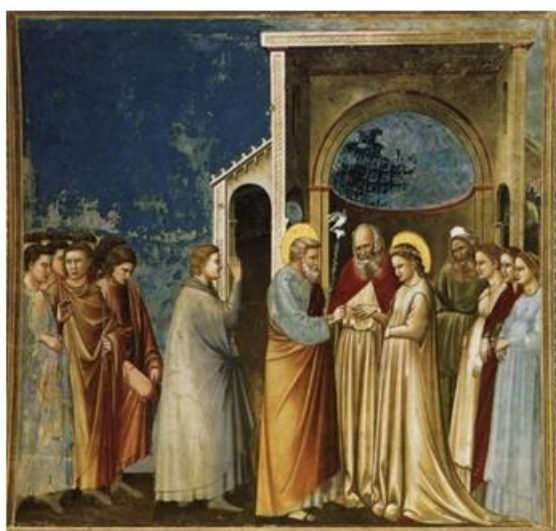

Görsel 40: Giotto, 1304-1306, fresko, $200 \mathrm{cmx} 185 \mathrm{~cm}$, No. 11 Bakire'nin Hayatından Sahneler: 5. Bakire'nin Evliliği

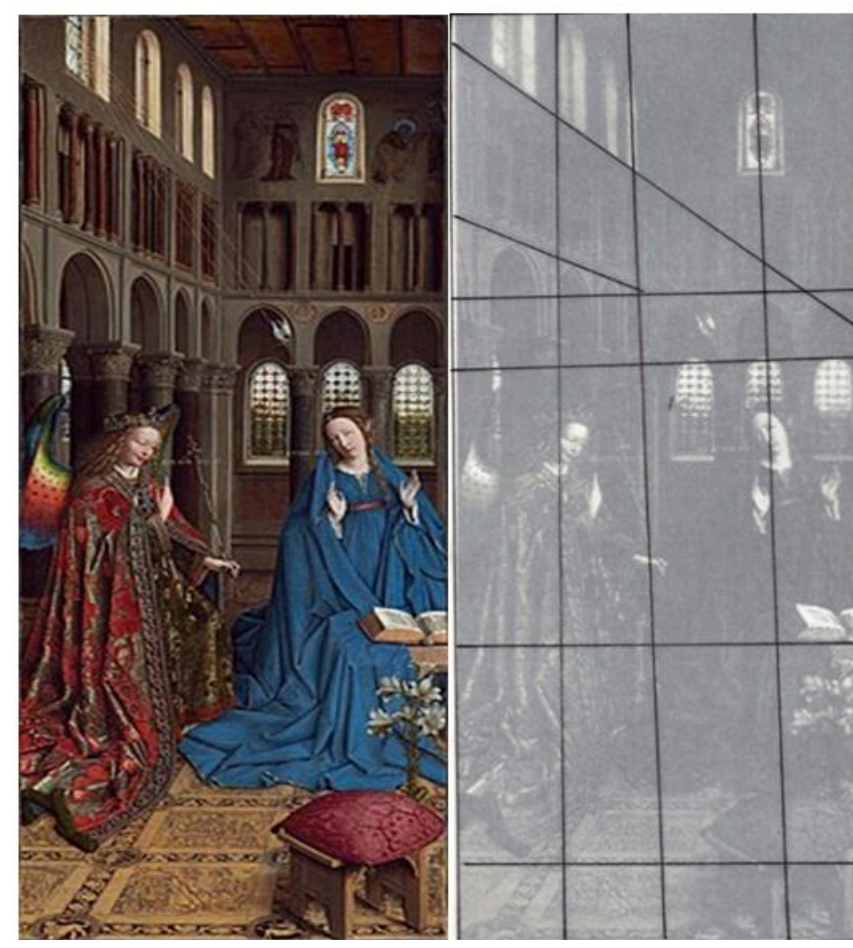

Görsel 41: Jan van Eyck, Annunciation, 1434-1436, National Gallery of Art /Washington ve Resmin geometrik kurgusu. (Hatice Karadoğan'ın tezinden)

52 | P a g e

www.iiste.org 
Gotik dönemi takip eden Rönesans döneminde, matematiksel bilgi çok önemsenmiştir. Uccello’nun (Görsel 42) "San Romano Savaşı" resmindeki asker figürü, rakursinin en iyi örneklerinden biridir. Sanatçı rakursi ile derinlik duygusunu, figürün gerçek görünümü ile değil görünen görünümüyle vermiştir. Resmin genelline bakıldığında her figürde kısaltım uygulanmış olduğu fark edilmektedir. Ayrıca ön- arka ve uzaklaşan figürlerin küçülmesi ile derinlik yanılsaması kuvvetlendirilmiştir. Yatay bir alanda figürlerin hareketi, diyagonal yol ve dikey formların kullanımı kompozisyonda denge sağlamıştır.

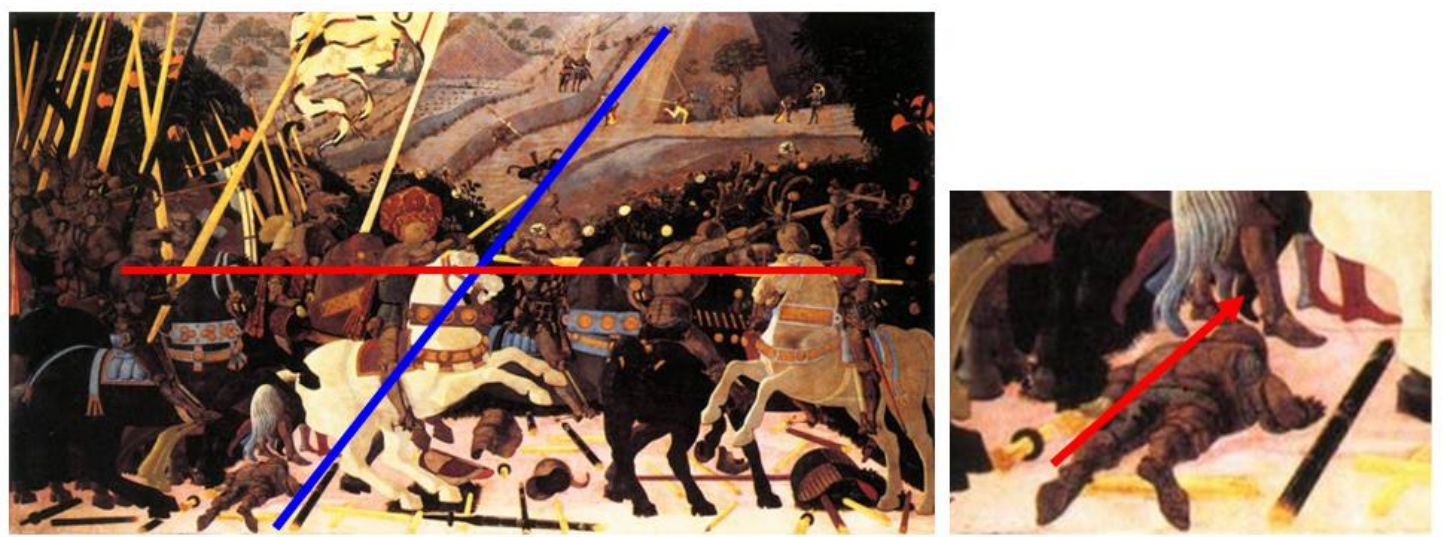

Görsel 42:Paolo Uccello, San Romano Savaşı,1456, 180 x 316 cm ve rakusi detayı(Hatice Karadoğan'ın tezinden)

Bir matematikçi olan Piero Della Francesco (Görsel 43) resmi ile Raffaello(Raphael)( Görsel 44) “ Atina Okulu" eserinde bilimsel perspektif kullanılmıştır. (Görsel 43) kubbe formu, (Görsel 44.) tabandaki geometrik formlarla perspektif güçlendirilmiştir. $\mathrm{Bu}$ dönem resimlerinde, mimari yapılar resmin elemanı olmuş ve perspektifin odak noktası simetrik eksen üzerinde oluşmaktadır. Piero Della Francesco Görsel 43.'de mimari kısımda bilimsel perspektif ve 1şığın geliş açısına göre 1şık-gölge hesaplanmış ile hacimselliği kuvvetlendirmiştir. (Ok 1şık yönü)
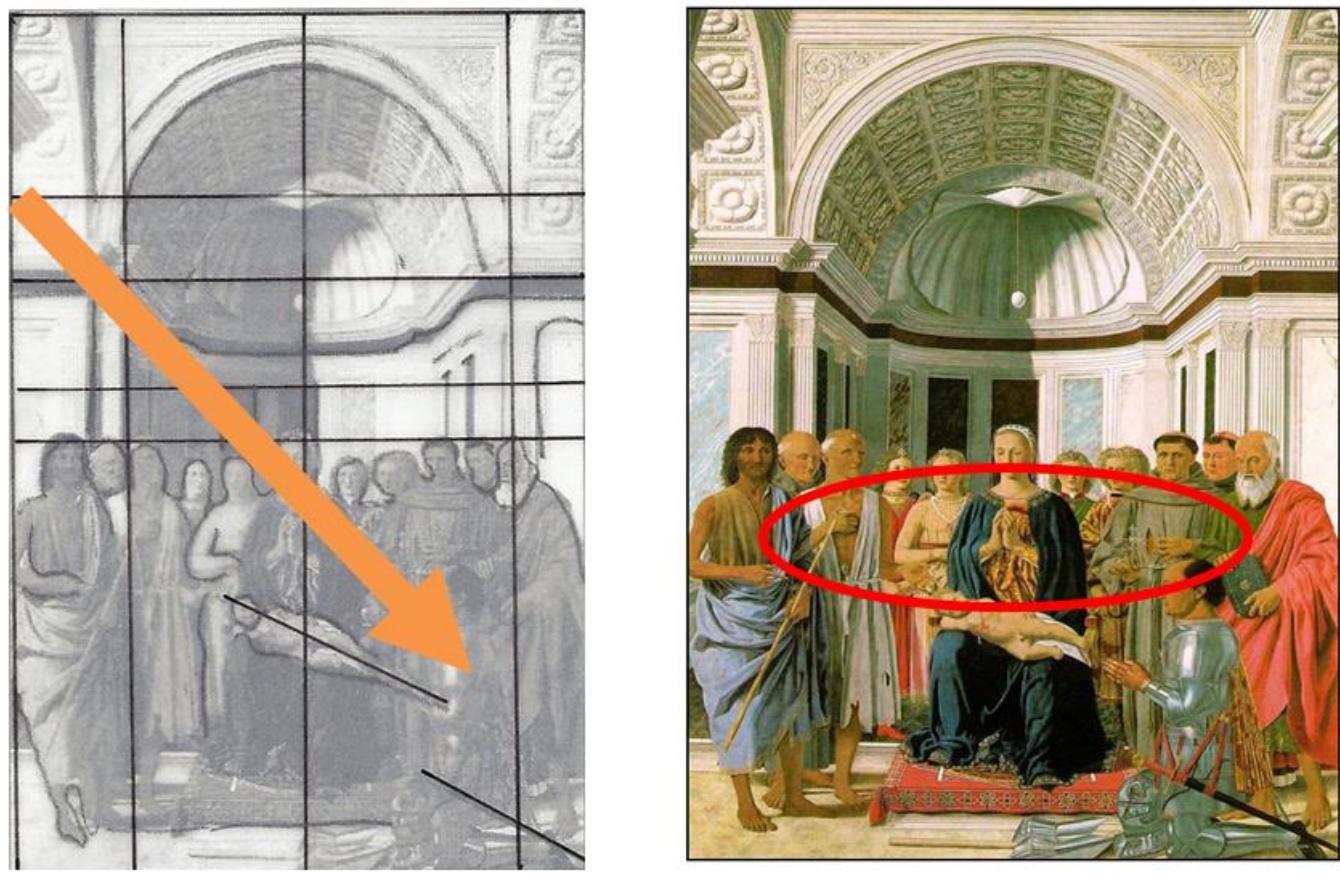

Görsel 43: Piero Della Francesco, Bakire ve Çocuk Azizelerle, 1472-1474, T.ü.y.b, 248x170cm, T.ü.y.b, Brera Sanat Galerisi /Milan, İtalya (Hatice Karadoğan'ın tezinden)

53 | P a g e

www.iiste.org 
Görsel 44.-45.'de filozof ve matematikçiler ünlü ressamların görselleri ile betimlenmiştir. Aynı resimde bu kişilerin birlikte verilmesi bütün bilimlerin birbirini etkilediklerine iyi bir örnek olarak gösterilebilir. Ayrıca bilimsel perspektifin uygulandığı iyi bir resim örneğidir. Bu resimde Öklid'in pergelle geometrik form çizimi, mimari yapıdaki kubbe formunun çiziminde matematiksel bilgiden yararlanıldığını vurgulanmak için olabilir.
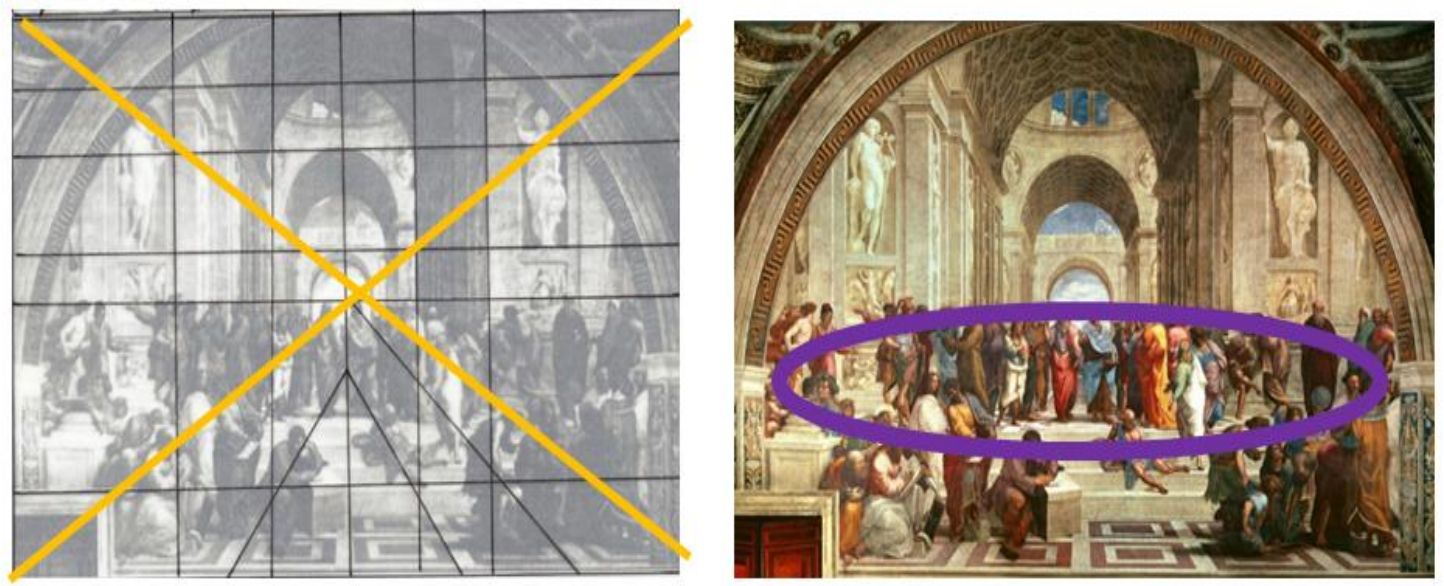

Görsel 44: Raffael'in, Atina Okulu, 1510-11, Fresk, Stanza della Segnatura, Vatikan/ Roma - İtalya ve resmin geometrik kurgusu. (Hatice Karadoğan'in tezinden)
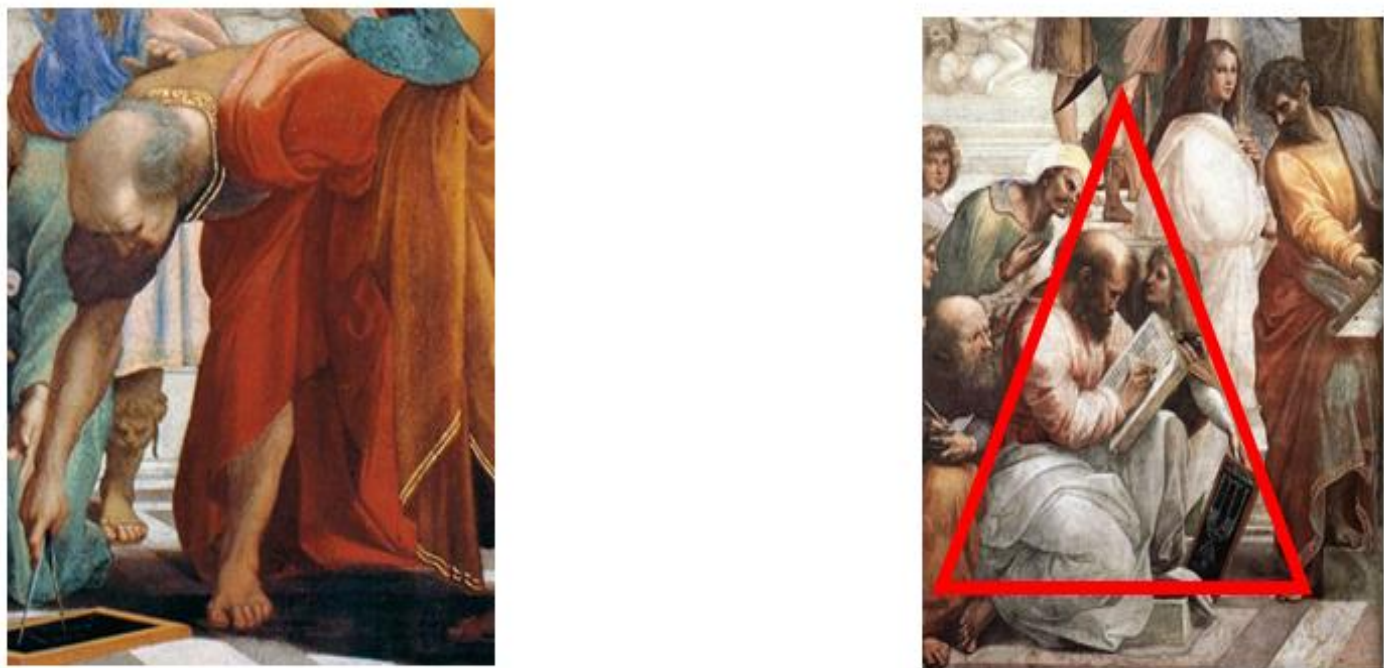

Görsel 45:Raffael'in "Atina Okulu" resminde bir detay; Öklid, elinde pergel ve Pisagor deftere bir şeyler yazıyor(Hatice Karadoğan'ın tezinden) 


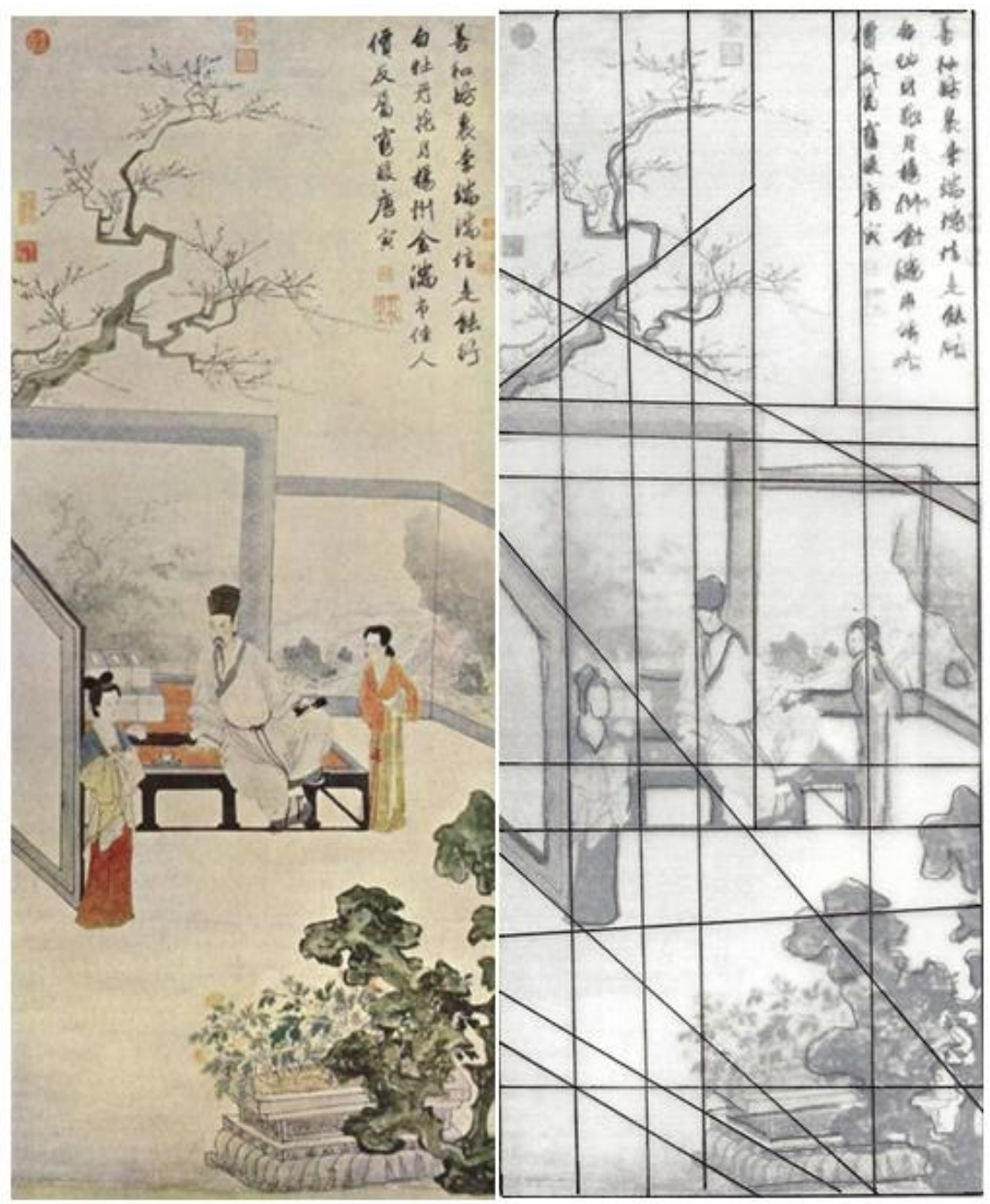

Görsel 46:Tang Yin, Şair ve iki fahişe,16.yy., T.ü.y.b., Ulusal Saray Müzesi/ Taipe - Tayvan

Derinlik yanılsaması sağlayan perspektif, aynı dönemlerde farklı kültürlerde farklı yorumlanmıştır. (Görsel 46.) 16.yy.'da Japon Tang Yin'in resminde perspektif; geometrik formların kaçışı çizgileri ile arkada görünen bitki formlarının, daha açık renkte(hava perspektifi ) ve daha küçük boyutlu gösterilmesiyle sağlanmıştır. Resimde dikey- yatay- eğik geometrik formlarla iç ile dış mekan kurgulanmıştır. Japon resminde espasın önemsendiği görülmektedir.

Rönesans'ta matematiğin bilgisine dayanan altın orana da önem vermiştir. Rönesans döneminde matematiksel bilgiyi resimlerinde en iyi uygulayan Leonardo da Vinci, hemen hemen bütün resimlerinde altın oran uygulamıştır. (Görsel 47.) Figürede hacimsellik Leonardo'nun kendi tekniği olan "sfumato", ile verilmiştir. Bilimsel perspektifin varlığı figürün sağ ve solunda yer alan eğrisel patika yol ve ağaçların yakında koyu ve büyük, uzaklaştıkça küçülmesi ve renginin açılmasıyla sağlanmıştır. Hava perspektifinden dolayı, uzak formların ayrıntılar belli oranlarda azalmaktadır. Yüzde ve bedende altın üçgen ve dörtgenleri görmek mümkündür. Altın oran da matematik bilgisi içeren bir kavram olup sanatta karşılı̆̆ını göstermiştir.

${ }^{*}$ Sfumato, boyalı yüzeyler arasında yumuşak geçiş, ışı alan ve almayan alanlarla kaynaştırılarak geçiş sağlanma.

55 | P a g e

www.iiste.org 

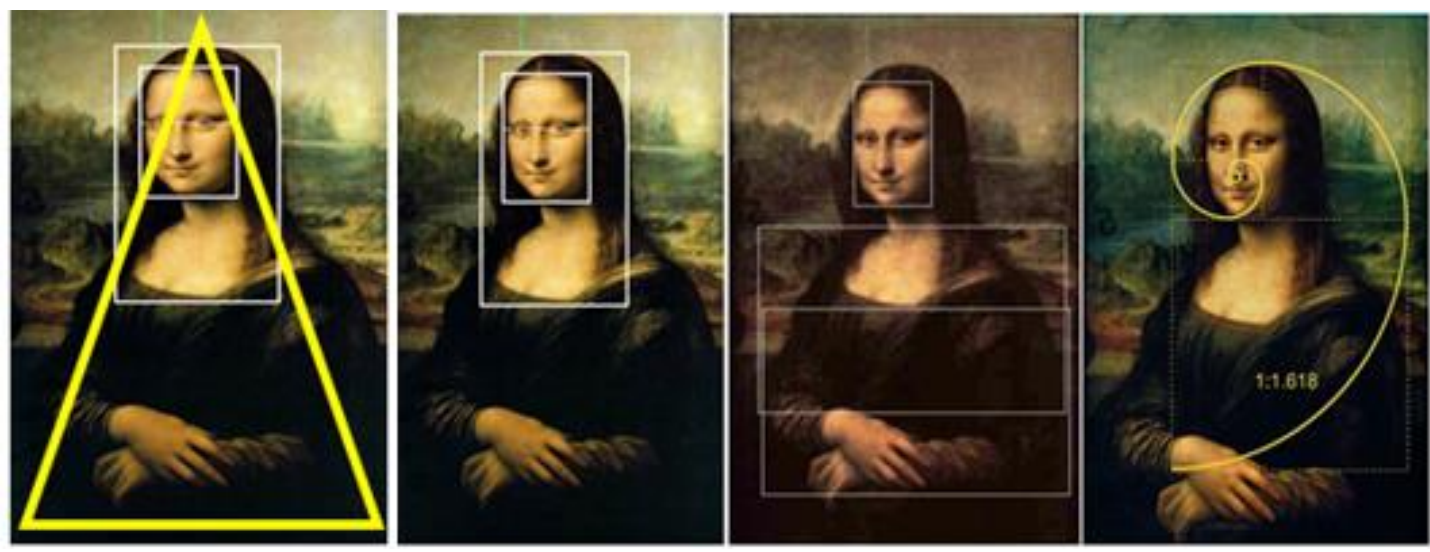

Görsel 47: Leonardo da Vinci, Mona Lisa, 1503, T.ü.y.b., 77 x 53 cm, Musée du Louvre / Paris Fransa, altın oran içeren "Mona Lisa” resmi ve şemaları(Hatice Karadoğan'ın tezinden)

(Görsel 48) Rakursi ve hava perspektifi kullandığı görülmektedir. Arkaya doğru git gide figürlerin boyutlarının küçülmesi, bilimsel perspektifi de uyguladığını göstermektedir. Küçük çocuk simetrik dengeyi bozarak, dengeli bir kompozisyona neden olmuştur. Yatay form; aile ile dışındaki figürleri birbirinden ayırmıştır. Açık havada yapılmış bir resim gibi 1şık-gölge ile hacimsel bir kompozisyon oluşturulmuştur. Ana figürlerin arkasında görünen yatay form simetrik olarak yüzeyi eşit bölmediği için resimde asimetrik denge sağlamıştır. Merkezi bir kompozisyondur.

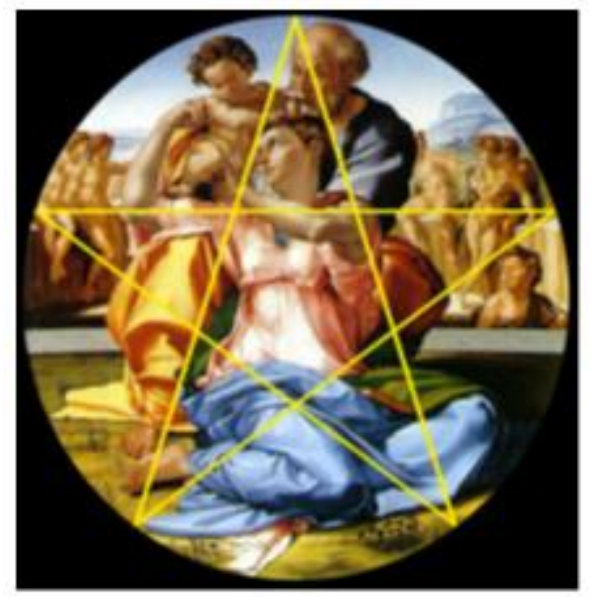

Görsel48: Michelangelo Bounarroti, Kutsal Aile, 1505, A.ü.t.,

120 x 120 cm, Uffizi Galeri / Floransa - İtalya ( Michelangelo'n'nun altın oran içeren "Kutsal Aile" resmi ve pentagram şeması) (Hatice Karadoğan'ın tezinden)

Rönesans’tan sonra bilimsel perspektifin önemi azalmış, oran orantı, altın oran gibi matematiksel kavramlar sanatta önemini yitirmeye başlamıştır. Görsel 49.'da Tintoretto,’Markus'un Cesedini Kurtarma" adlı eseri Maniyerist bir eserdir. Tek kaçışlı perspektif yerine çok kaçışlı bir perspektif örneğidir. Yüksek Rönesans'ın durağan anlatımından sıkılan ressamlar, resimlerinde hareketi yakalamak için "S” formunda düzenlemelere geçmişlerdir. Michelangelo'nun sanatından etkilenen dönem sanatçıları Yüksek Rönesans'ın ölçü ve simetri anlayışına bir tepki olarak Maniyerizm üslupla eserlerini yapmışlardır. Bu dönem eserlerinde oran ve orantının bozulması resimde uyum ve dengenin de bozulmasına neden olmuştur. El Greco'nun Görsel 50.'de Maniyerist olan bu resim figürlerin orantısızlığı uçuşan figürler, Rönesans'ın yere basan figürlerinden farklıdır. Işık-gölge ile hacimsellik yakalanmıştır. Tek odaklı perspektif görülmemektedir. Büyük bir figürün önde oluşu ve zemindeki koyuluğun dağılımı derinliği güçlendirmiştir.

Maniyerizmde; figürde ölçü, oran ve orantı reddedilmiş, devamında tek odaklı bilimsel perspektifin reddiyle Barok dönem başlamıştır. Bu çıkışlar, sonra gelen üslup ve akımlara örnek olmuştur.

56 | P a g e

www.iiste.org 


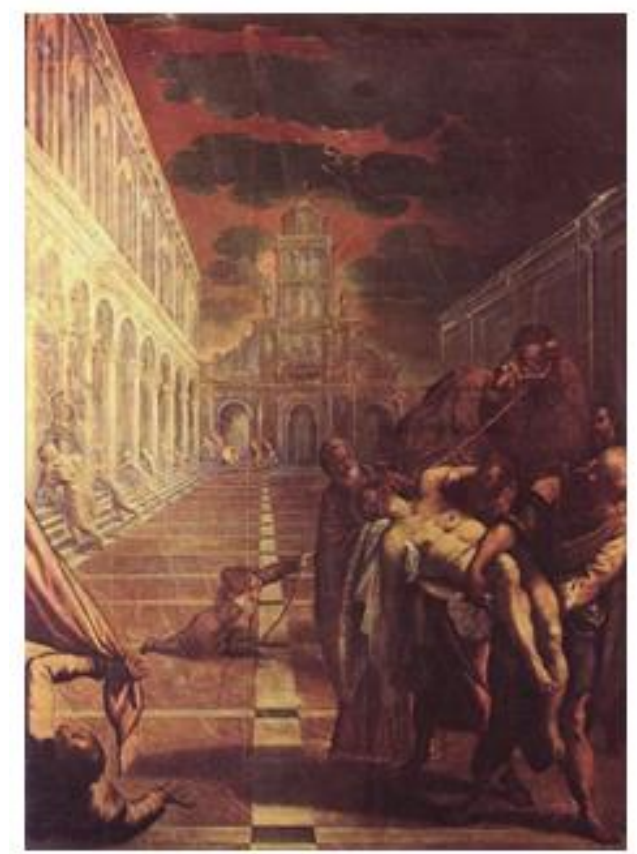

Görsel 49: Tintoretto, Markus'un cesedini kurtarma, 1562/66, T.ü.y.b., 421 x $306 \mathrm{~cm}$, Akademi Galerisi / Venedik - İtalya

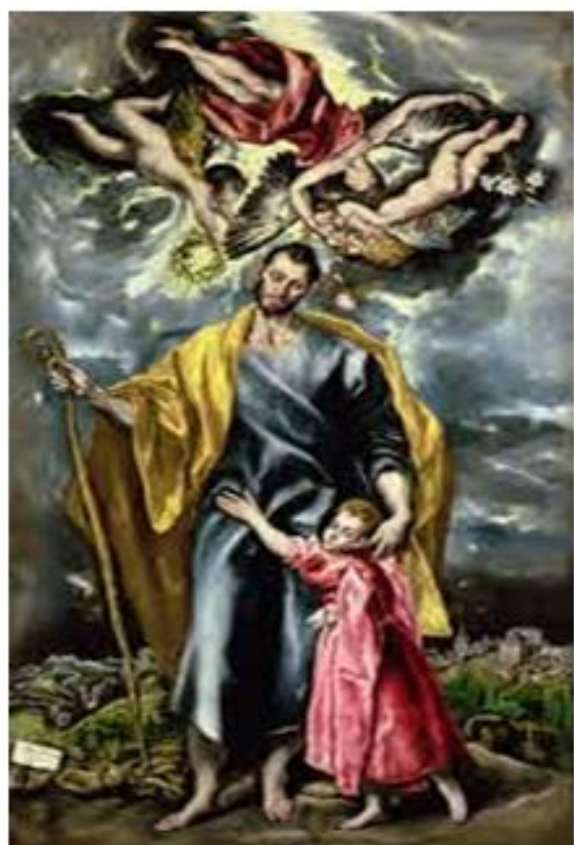

Görsel 50: El Greco, Saint Joseph And The Christ Child, 1597-99 (oil on canvas) $109 \times 56 \mathrm{~cm}$

Barok dönem eserlerinden biri olan, Andrea Pozzo'nun ünlü eseri “Cizvitlerin Misyonerliğine Alegori”'isimli eseri (Görsel 51) hem hava hem çizgi perspektifi kullanmasından dolayı önemli bir eserdir. Yan duvarlardaki mimari yapı tavana doğru mimari bir çizimle, resimsel olarak devam ettirilip sonsuzluk, hava perspektifi ile sağlanmıştır. Tavanda görülen mimari yapı resmi, bilimsel perspektifle dört yönde ayrı ayrı tek odak noktalı olarak gözükmektedir. Bu derinlik yanılsaması, Op-Art resimlerde olduğu gibi, optik bir yanılsamadır. Bu yanılgı hava perspektifi ile sağlanmıştır. Ayrıca, figürlerde rakurside gözlemlenmektedir. $\mathrm{Bu}$ resmin geometrik kurgusu diyagonal doğrultularda, bu da kompozisyonda hareketliliği sağlamaktadır. Sonsuzluğa doğru hava perspektifi ile figürler betimlenmiştir. $\mathrm{Bu}$ mimari çizimler ve sonsuzluk fikri matematiğin kavramları olduğundan resim sanatında da karşılı̆̆ını bulmuştur.

$\mathrm{Bu}$ resmin geometrik kurgusu değişmemiştir. Diyagonal doğrultuların resme hareket kattığı, tabana dik inen doğrultuların resimde denge sağladığı yatay doğrultuların durağanlığı sağladığ1 ayrıca yataydikey-diyagonal(eğik) doğrultuların birlikte olması kompozisyona denge sağladığı düşünülmüştür. 

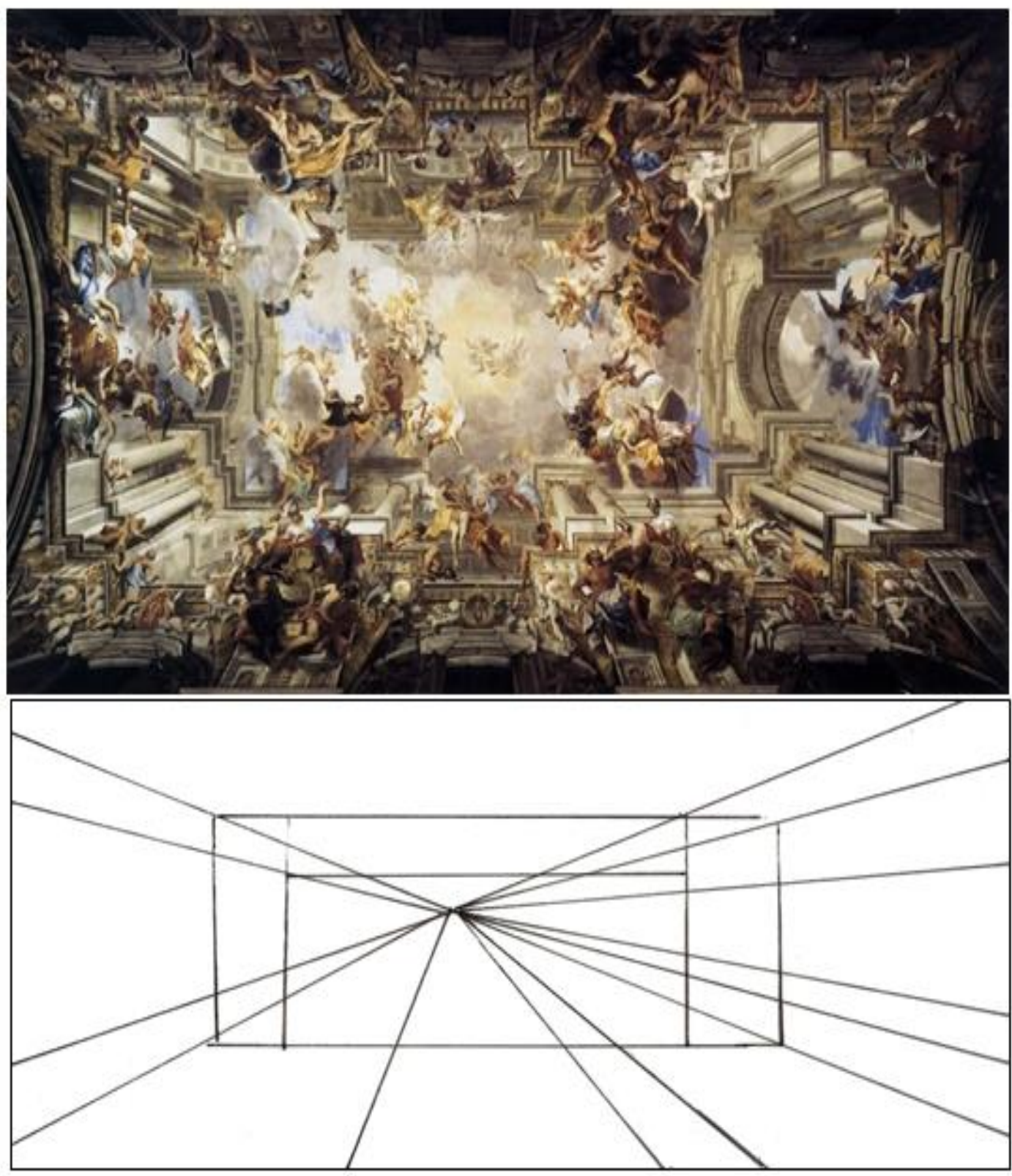

Görsel 51: Andrea Pozzo, Cizvitlerin Misyonerliğine Alegori,1661. San Lgnazio Kilisesi’nde tavan resmi, Roma ve Resmin Geometrik Analizi(Hatice Karadoğan'ın tezinden)

Rönesans'ta derinlik yanılsaması bilimsel perspektifle sağlanmaya çalışılırken; bu yanılsamayı 19.yy da Cézanne, (Görsel 52) yatay ve ön arka formlarla yakalamıştır. Cézanne resmi üçgen kompozisyon örneğidir. Yol dörtgen formuyla perspektif ve derinlik üçgen formunun küçülmesiyle sağlanmıştır. Hacimsellik sorununa modern resimde her sanatçı farklı çözümler getirmiştir. Görsel 53'de geometrik prizmalar ve ön- arka, üst-alt geometrik formlarla yüzeyde hacimsellik sağlanmıştır. Uzaysal bir alan kurgusu görülmektedir. Soyut geometrik resimlerde, objeler hacimsel gösterilmez hacim fikrini vermeye çalışır. 


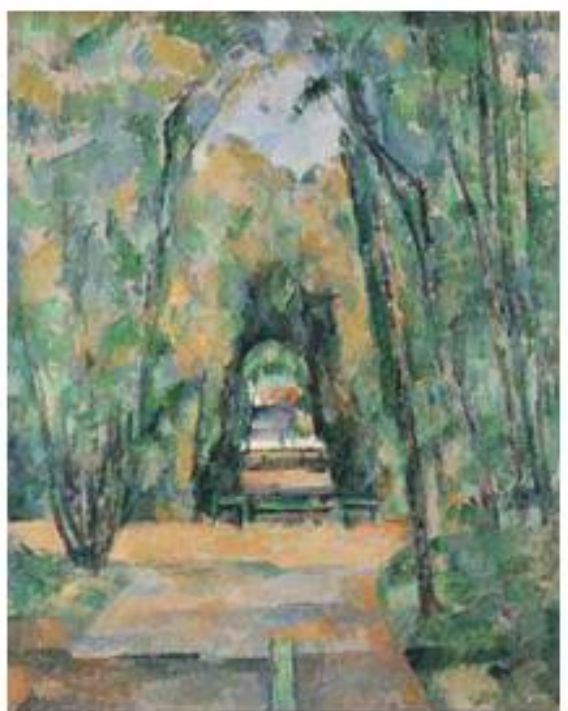

Görsel 52: Cezanne, Avenue at Chantilly 1888 , yağlıboya, $82 \times 66 \mathrm{~cm}$, National Gallery, London

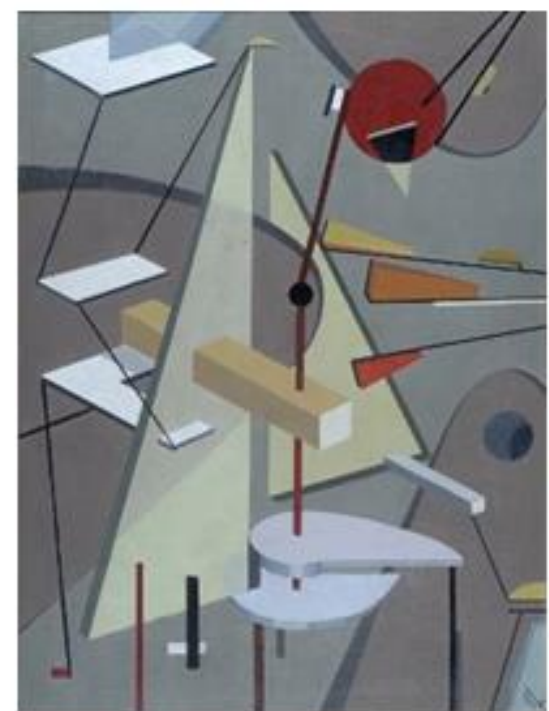

Görsel 53: El Lissitzky,

Suprematizm, , $1920-1929,81$ x $60 \mathrm{~cm}$.

Matematiğin araç ve gereçlerinden olan iletki ve pergel matematiksel hesap gerektiren Op-Art gibi resimlerde kullanılmaktadır. Fikir spontane fakat yapılan işlemler spontane değildir. Turanî geometrik form içeren resimlerin belli bilgi gerektirdiğini şöyle yorumlamaktadır; Geometrik biçimli motiflerle bunların kompozisyonunu oluşturmanın akli bir işlem olduğu düşünülebilmektedir. Çünkü geometrinin, mantık ve bilinçli bir işlem olduğu açıktır. Bu nedenle, uygulanan geometrik işlemlerin ancak önceden düşünülerek bilinçli yapılacağı akla gelmektedir. (Turanî,1978) Viktor Vasarely'nin resimlerinde de geometrik form olan kare formuyla üç boyutlu optik yanılsama sağlayan, prizmalar oluşturulmuştur. Viktor Vasarely üç boyutlu bir yanılsama için optik denemelerle ve belli hesaplarla bu eserler tasarlamıştır.
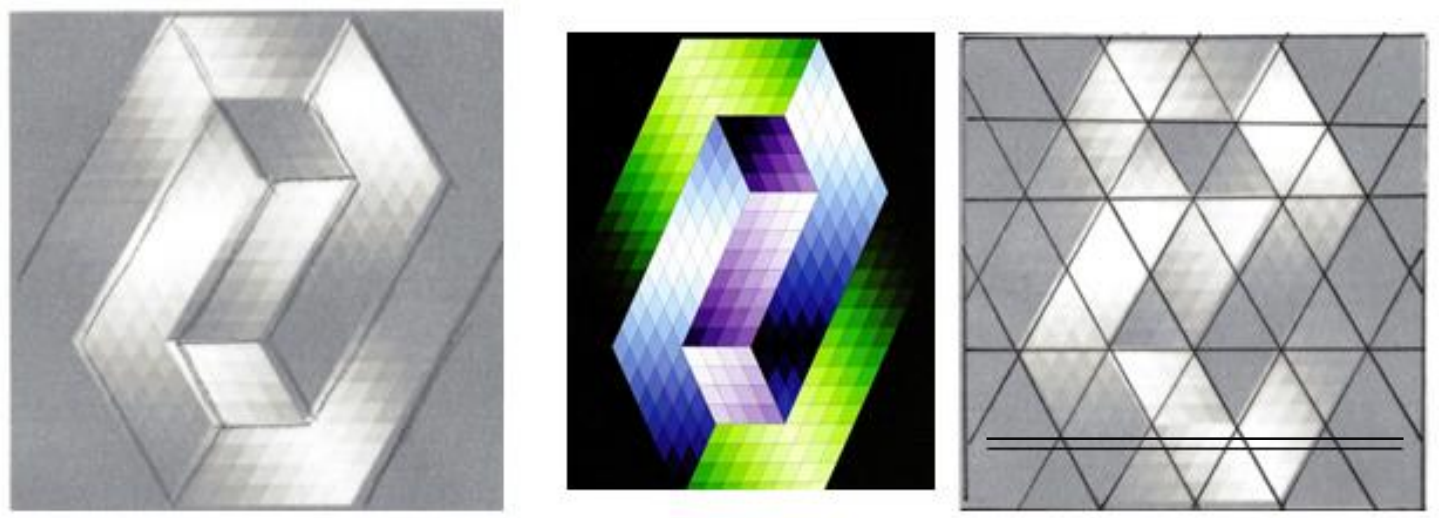

Görsel 54:Victor Vasarely, 1968, Keple Gestalt, T.ü.a.b., 160 x 160cm ve geometrik kurgu şemas1

Victor Vasarely’nin, Görsel 54.'de dikey-yatay ve diyagonal formlar resmin geometrik şemasını oluşturmaktadır. Matematiğin hacim kavramı, bu resimde iki soğuk rengin 1şıkla hacimsellik sağlaması ile karşılık bulmaktadır. Tekrar eden formlar ritim sağlanmıştır. Viktor Vasarely'nin Keple Gestalt ${ }^{*}$ resimlerinde yer alan öndeki prizma hem aşağı ve sola dönük, hem yukarı ve sağa dönük görülebilmektedir. Ayrıca, bu matematiksel formların bir bütün olarak algılanması, tümdengelim bir matematiksel yaklaşımdır. Önce bütün algılanmaktadır. Sonra detaylar, parçalar yani kare formu fark

* Gestalt görsel algılama, bütün olarak algılama, şekil zemin alglst.

59 I P a g e

www.iiste.org 
edilmektedir. Viktor Vasarely bu resimde kare formunu belli bir düzen ve renk ile 1şık vererek üç boyutlu bir optik yanılsama sağlamıştır.

Sürrealist akımın, resimdeki önemli temsilcilerinden olan Belçikalı Rene Magritte(1898-1967) eserlerinde çelişkilere ve imkânsızlıklara yer vermiştir. Çelişkiler ve imkânsızlıklar matematiğin terimleri olup bazı sanatçılar tarafından görsellerle de ifade edilebilmektedir. Bu tür çalışmalar matematiğin zihinselliğinin görsel izdüşümü olarak düşünülebilir. Bu resimlerde doğa ve doğa diş1 oluşumlar aynı düzlemde kurgulanmaktadır. Görsel.55.'de Rene Magritte, "The Blank Seeing” de görünmemesi gereken ağaç gövdeleri, hatta boşluk, ön plandaki attın önüne geçmektedir. Böyle bir görünüm imkânsızdır. Fakat bu resimde, bu imkânsızlıklar mümkün gösterilmiştir. Ayrıca bu resimde hava perspektifi ve ışık-gölge ile hacimsellik sağlanmıştır.

Görsel 56' de bir iç mekân, beş yüzeyi ile ayrı ayrı perspektifsel olarak yorumlanmıştır. Birçok bakış açısı düşünülerek resim kurgulanmıştır. Bakılan noktaya göre nesneler ve mimari yapı aynı anda hem aşağıda hem yukarıda, hem sağda hem solda betimlenmiştir. Uzay boşluğu betimlemesi içinde sonsuza doğru ilerleyen imkânsız bir iç mekân planı ve mimari yapı, imkânsız nesneler, geometrik formlar, gözlemlenmektedir. Sonsuzluk, matematiğin bir kavramıdır. Görsel 56.'in geometrik analizine bakıldığında köşegen çizgileri, paralel çizgiler ve dik çizgiler kontrast bir geometrik kurguyu oluşturmuştur.
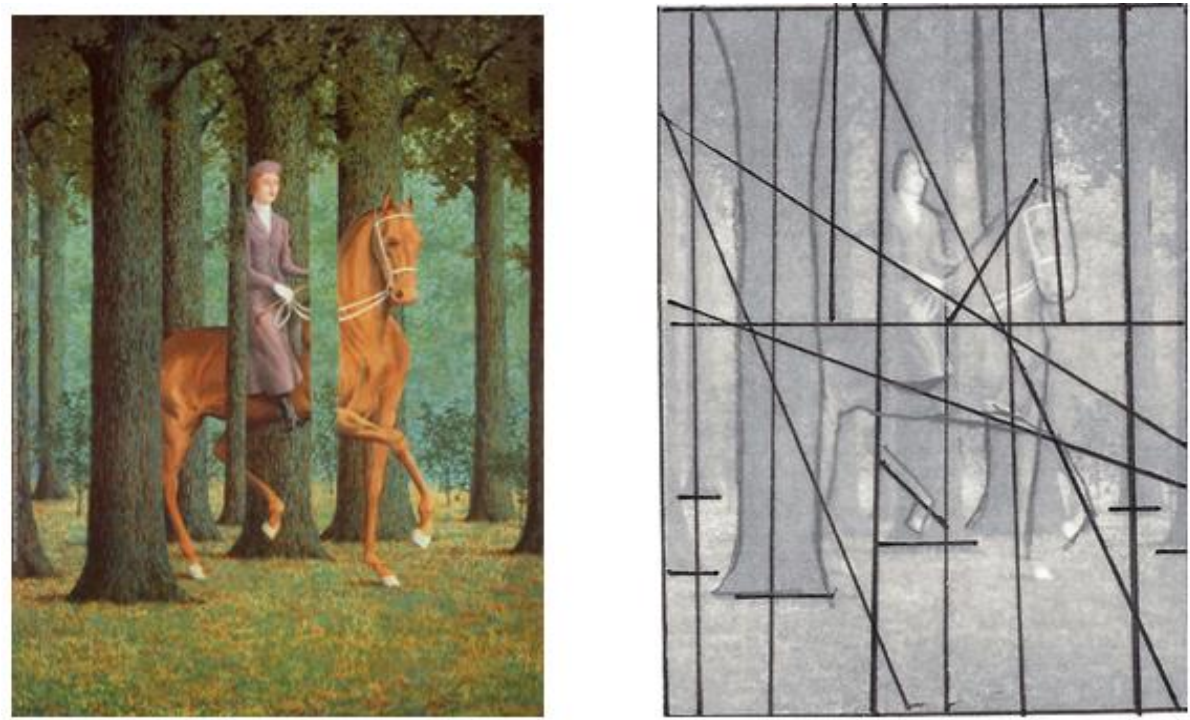

Görsel 55: Rene Magritte, Boş Görünce ( The Blank Seeing), 1965, T.ü.y.b., 81x65cm, Ulusal Sanat Galerisi,Washington D.C(Hatice Karadoğan'1n tezinden)
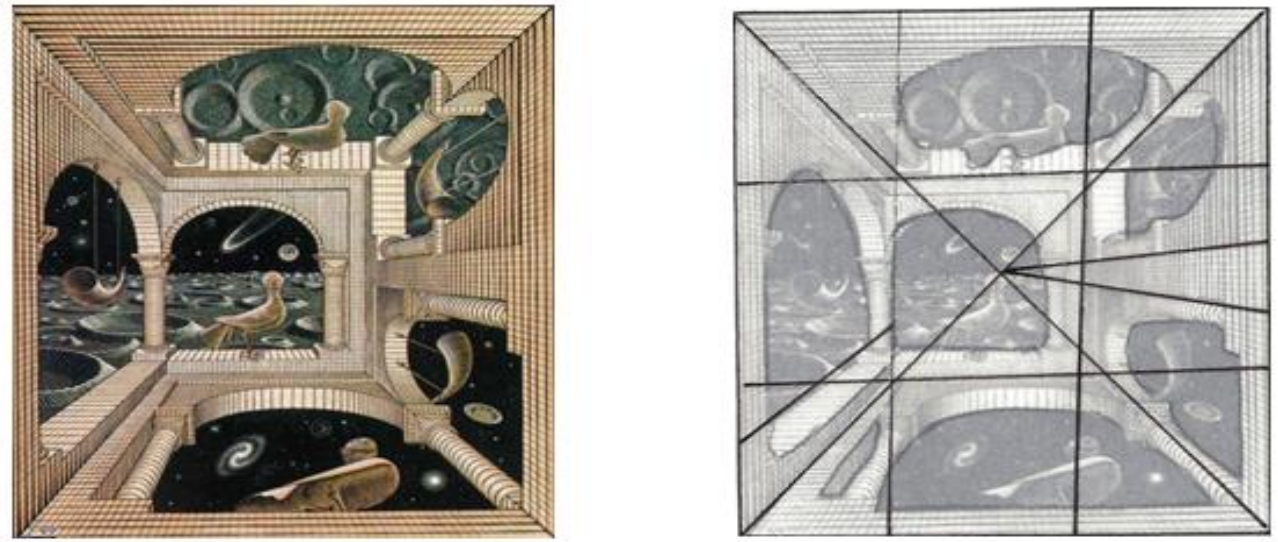

Görsel 56: Maurits Cornelius Escher, ”Öteki Dünya” ağaç gravür ve ağaç baskı, 1947 ve resmin geometrik analizi (Hatice Karadoğan'ın tezinden)

$60 \mid \mathrm{P}$ a g e

www.iiste.org 
Yapılan analizlerden edilen bilgiler doğrultusunda şu sonuçlara ulaşılabilir: Bazı dönemlerde ve akımlarda matematiğin formları, işaretleri kullanılırken bazı dönemlerde matematiğin perspektif, altın oran, simetri, ritim, denge gibi kavramları görsellerle resim sanatında görülmüştür. Ayrıca resmin geometrik kurgusu da resim sanatında önemsenen matematiksel bilginin kullanılmasına dayanır. Bazı sanatçılar ve dönemlerde ise doğaçlama olarak içsel bir mukayeseyle yani sezgisel olarak eserler oluşturulmuştur. Soyut resimlerdeki geometri, kompozisyonu dengeli düzenlenmesine katkı sağlarken; geometrik soyut resimlerde birbirini dik kesen doğrultular ve geometri formlar önemlidir. Figüratif resimlerde ise kompozisyonun geometrik kurgusu yani yüzeyin çizgisel şeması figür ve formların düzenine bağlıdır. $\mathrm{Bu}$ geometrik şema denge, kontrastlık, ritim gibi resimsel değerleri içinde barındırmaktadır. Geometrik şema; çizgi, renk, doğrultu ve biçimlerle desteklenmektedir.

\section{SONUÇ}

Birbirinden farklı bu iki disiplin olan matematik bilimi ve resim sanatı her dönem etkileşim içinde olduğu görülmüştür. Matematiğin bilgi olarak resimde varlığı, perspektif, altın oran, ölçü, denge, harmoni kompozisyonun geometrik kurgusu olarak yer alırken, görselliği ise, matematiğin sembolleri ve işaretleri, geometrik formlar ve biçimlerdir. Bazı resimlerde matematik bilgi, bazılarında görsel, bazılarında ise her ikisi birlikte görülmektedir.

Rönesans döneminde matematiksel bilgiye önem verilmiş; ölçü, altın oran, perspektif, geometrik kurgu gibi matematiksel bilgiler kavramsal olarak resimde kullanılmıştır. Maniyerizm'le birlikte ve devamında Barok dönemde ise matematiğin bilgisinin Rönesans resmindeki karşıllı̆ı reddedilmiş ve matematiksel kavramlar farklı yorumlanmış ve daha serbest yaklaşımlarla kompozisyonlar yaratılmıştır.

19.yy ve 20.yy.da dünya ülkelerinde yaşanan siyasal ve sosyal gelişmeler, sanat dünyasını da yakından etkilemiş ve bu etkilerin sonucu da çeşitli sanatsal hareketler, bireysel ya da grupsal olarak başlamıştır. Modern ve avangart yaklaşımlarla resim sanatı şekillenmiş ve günümüzde de bu etkileşim devam etmektedir. Bu dönem resimlerinde genelde matematiğin görselleri kullanılmıştır.

Rönesanstan önce matematiğin görselleri ve geometrik formlar kullanılırken Rönesansta matematiğin bilgisi kullanılmış, modern resim ile özellikle soyutlamalar ve soyut resimle birlikte Rönesans öncesi resmi gibi tekrar matematiğin görselleri resimde yer almaya başlamıştır. Soyut resimde matematiği bilgi olarak renk kullanımı ve ön-arka formla derinlik yanılsaması, simetrik-asimetrik formların seçimi, kompozisyon kurgu, formların ölçü ve dengesi de matematiğin hem bilgisi hem de zihinsel ve sezgisiyle olmuştur.

Sonuç olarak, matematik ile resim sanatının etkileşim içinde olduğu, bazı dönem ve sanatçılarının bilinçli ya da bilinçsiz olarak resimlerinde matematiğin bilgisinden ve görsellerinden yararlandığı görülmüştür.

\section{KAYNAKÇA}

Gombrich, E.,H.,(1997), Sanatın Öyküsü, Remzi Kitapevi, İstanbul

Johnston, G.,(1993), Resim Sanat, Remzi Kitapevi, İstanbul

Klee, P., (2006), Çağdaş Sanat Kavramı,Dost KitapeviYayınları, Ankara

Komisyon,(2010), iki Boyutlu Sanat Atölyesi, Meb. Yayınları, Ankara

Mirza, H.,(2009), Sanat Eserleri Inceleme 12, MEB Yayınları, Ankara

Sezgin,(2011), Temel Felsefe Bilgileri, Karekök Yayınları, İstanbul

Tansuğ, S., (2006), Resim Sanatı Tarihi, Remzi Kitapevi, İstanbul 
Turanî, A.,(1978), Resimde Geometri/ İşlemleri- Sorunları, Türkiye İş Bankası Kültür Yayınları, Ankara

Tez: Karadoğan, H., (2013)“Matematiksel Görsellerin Resimle İlişkisi”, Yeditepe Üniversitesi, Sosyal Bilimler Enstitüsü, Güzel Sanatlar Fakültesi Plastik Sanatlar Yüksek Lisans Tezi, , İstanbul

http://www.megep.meb.gov.tr/mte_program_modul/moduller_pdf/Antik\%20Form\%20Tasar\%C4\% B1m\%C4\%B1.pdf

\section{Görseller Listesi}

Görsel 1: Altamira Mağarasında bulunan hayvan kemikleri ve üzerinde görülen çentikler http://donsmaps.com/altamirapaintings.html

Görsel 2: Lascaux Mağarası, Fransa, https://en.wikipedia.org/wiki/Lascaux

Görsel 3: Çatalhöyük’te bulunan çanak ve çömleklerde geometrik formlara rastlanmıştır.( Kalkolitik döneme MÖ 5500-5000) https://tarihegitimi.blogspot.com/2019/02/catalhoyuk.html

Görsel 4: Sümer çivi yazısı ve Mezopotamya(Sümer resim sanatı MÖ.4000-2000), https://www.neoldu.com/tarihi-degistiren-kavim-sumerler-120h.htm

Görsel 5:Mezopotamya Sanatı, Uruk Dönemi silindir mühür ve tablet, MÖ 2600

https://tr.wikipedia.org/wiki/Mezopotamya_sanat\%C4\%B1\#/media/Dosya:Flickr_-_Nic's_events__British_Museum_with_Cory_and_Mary,_6_Sep_2007_-_185.jpg

Görsel 6: Misır resimleri ve hiyeroglifleri

Görsel 7: Pişmiş Toprak .Hacılar (M.Ö 7500-3000) Neolitik Çă̆ (M.Ö 8.000 - 5.500) http://www.megep.meb.gov.tr/mte_program_modul/moduller_pdf/Antik\%20Form\%20Tasar\%C 4\%B1m\%C4\%B1.pdf

Görsel 8: Riton içki kabı, (çarık şeklinde) Asur Ticaret Kolonileri Çağı (M.Ö.1950-1750) Kültepe

http://www.megep.meb.gov.tr/mte_program_modul/moduller_pdf/Antik\%20Form\%20Tasar\%C4\% B1m\%C4\%B1.pdf

Görsel 9:Frig dönemi(M.Ö.1200-700)

http://www.megep.meb.gov.tr/mte_program_modul/moduller_pdf/Antik\%20Form\%20Tasar\%C4\% B1m\%C4\%B1.pdf

Görsel 10: Yunan geometrik form içeren vazo(Proto Geometrik Dönem ve Basit hayvan figürlü geometrik vazo, Geometrik Dönem, Louvre Müzesi

https://www.sosyalarastirmalar.com/cilt11/sayi59_pdf/3sanat_sanattarihi_arkeoloji_mimari/yuk sel_ismet.pdf

Görsel 11: San Vitale Kilisesi Ravenna, 526-547

Görsel 12: Selanik’te bir kiliseden mozaikler. 7.- 8. yy.

Görsel 13: Albrecht Dürer,1514, gravür, 24x18,8cm ve sihirli karenin ayrıntısı ～( Hatice Karadoğan'ın yüksek Lisans tezi )

62 | P a g e

www.iiste.org 
Görsel 14: Pisagor Kendi Okulunda adlı resim ve Pisagor üçgeni

Görsel 15: Grogor Reisch, Bayan Aritmetik(Madame Arithmatica),1508, Abaküs adlı hesap tablosu

Görsel 16: Van Gogh, Volta, 1890, 80x64cm, T.ü.y.b., Pushkin Müzesi /Moskova-Rusya

Görsel 17: Paul Cézanne, Mont Geroul'da Sokak, 1899,65 x 52 cm, Yağlıboya, Post Empresyonist, Whitney Museum of American Art New York https://www.istanbulsanatevi.com/sanatcilar/soyadi-c/cezanne-paul/paul-cezanne-montgeroulda-sokak-122/

Görsel 18: Picasso, 1911, Still Life with a Bottle of Rum, oil on canvas, $61.3 \times$ $50.5 \mathrm{~cm}$, Metropolitan Museum of Art, New York

https://en.wikipedia.org/wiki/Pablo_Picasso\#/media/File:Pablo_Picasso,_1911,_Still_Life_with_a_ Bottle_of_Rum,_oil_on_canvas,_61.3_x_50.5_cm,_Metropolitan_Museum_of_Art,_New_York .jpg

Görsel 19: Braque, Kemanlı Adam, 1912 , T.ü,y.b., 100 x 73 cm, E.G. Buhrie Coll. Vakfi/ Zürih İsviçre

Görsel 20: Wassily Kandinsky, 1924, Contrasting Sounds, Geometric abstraction, Oil on cardboard, $70.0 \times 49.5 \mathrm{~cm}$, https://www.wassilykandinsky.net/work-237.php

Görsel 21: Max Bill, Construction in 19 Squares, 1941, gouache on board, $102 \mathrm{x}$ 72cmhttp://www.saturationpoint.org.uk/max_bill

Görsel 22: Tangram oyunundaki geometrik formlar

Görsel 23: Theo van Doesburg, Karşı Kompozisyon V, 1924, T.ü.y.b., 100 x 100cm, Özel Koleksiyon

Görsel 24: Mondrian, Kırmızı Mavi ve Sarı Kompozisyon II, 1930

Görsel 25: Malevich Kasimir, Siyah ve Kırmızı Kare, 1915,T.ü.y.b., 71,4 x 44,4 cm, Modern Sanatlar Müzesi / New York - Amerika

Görsel 26: Frank Stella, 1970, Resim, 304.8 x 762 cm https://learn.ncartmuseum.org/artwork/raqqa-ii/

Görsel 27: Paul Klee, Nil Efsanelerinden, 1937, Çuval bezi üzerine pastel, 69x61 cm, Kunstmuseum / Berne - İsviçre

Görsel 28: Jasper Johns, Renkli 4 rakamı, 1959, tuval üzerine yağ, sicak balmumu,kolaj, 51.4 x 39.4 cmhttps://www.mutualart.com/Artist/JasperJohns/8541518AF93D42D4/AuctionResults?tags=1 9EFD20D308FB8EE\&artworkSort=63CF4ACB1F6AE76

Görsel 29: Antoni Tapies, Antoni Tapies, "Esperit Catalia II" Etching, Signed Edition, 1974, etching with embossing on Guarro paper, 19"hx $25 \mathrm{lw}$ https://www.mutualart.com/Artwork/Antoni-Tapies--Esperit-Catalia-II-Etchi/0E666BB3A2DE0FD8 
Görsel 30: Jackson Pollock, Guardians of the Secret, 1943, Oil on canvas, $122.9 \times 191.5 \mathrm{~cm}$ San Francisco Museum of Modern Art (SFMOMA) https://www.artsy.net/artwork/jackson-pollockguardians-of-the-secret

Görsel 31: Adolph Gottlieb, Untitled, 1965, acrylic and ink on paper, 51.1 x $66.4 \mathrm{~cm}$. https://www.mutualart.com/Artwork/Untitled/A410543479F154F4

Görsel 32: Sengai Gibon, Çember, Üçgen ve Kare, 19.yy., K.ü.m., 28.4 x 48.1 cm, Idemitsu Sanat Müzesi, Tokyo Hatice Karadoğan'1n yüksek Lisans tezi

Görsel 33: Halil Akdeniz, 1994, Anadolu Uygarlıkları - Kültürlerarası, 115.00 x 104.50 cm.Tual üzerine akrilik, Özel Koleksiyon,

http://www.lebriz.com/pages/artist.aspx?section=130\&lang=TR\&artistID=447\&bhcp=1\&periodID $=536$

Görsel 34: Laszlo Moholy Nagy,1920,Large Railway Painting

Oil on canvas, 100 x $77 \mathrm{~cm}$, Museo Nacional Thyssen-Bornemisza, Madrid https://www.oceansbridge.com/shop/museums/thysen-bornemisza/large-railway-painting-1920

Görsel 35: Misır resmi ve resmin geometrik analizi, https://www.muhendisbeyinler.net/antik-misirmatematigi-ve-misir-medeniyetinin-matematige-katkilari/

Görsel 36: Matematiğin matris formu,

Görsel 37: Yunan Vazosu ve Ayak ayrıntısı, Savaşa Hazırlanan Genç, M.Ö.510-500 dolayları," Euthymedes imzalı; yüksekliği 60cm; Staatliche Antikensammlungen und Glyptotkhek, Münih (Gombrich, Sanatın Öyküsü kitabından taratıldı.) Hatice Karadoğan'ın yüksek Lisans tezi

Görsel 38: M.S 520 dolayları, Ekmek ve Balık Mücizesi, Mozaik, S.Apollinare Nuovo Bazilikas1, Ravenna, Roma Sanat, (Gombrich,1997) ve geometrik kurgu analizi.

Görsel 39: İsa Havarilerin ayaklarını yıkıyor,1000 dolayları, III. Otto İncili’nden Bayerische Staatsbibliothek, Münih ve Resmin geometrik kurgusu

Görsel 40: Giotto, 1304-1306, fresko, 200 cmx185 cm, No. 11 Bakire'nin Hayatından Sahneler: 5. Bakire'nin Evliliği,https://commons.wikimedia.org/wiki/File:Giotto_di_Bondone_No._11_Scenes_from_t he_Life_of_the_Virgin_-_5._Marriage_of_the_Virgin_-_WGA09183.jpg

Görsel 41: Jan van Eyck, Annunciation, 1434-1436, National Gallery of Art /Washington ve Resmin geometrik kurgusu.

Görsel 42:Paolo Uccello, San Romano Savaş1,1456, 180 x 316 cm ve detay Hatice Karadoğan'ın yüksek Lisans tezi Görsel 38: Paolo Uccello, San Romano Savaşı'nın geometrik analizi. Hatice Karadoğan'ın yüksek Lisans tezi

Görsel 43: Piero Della Francesco, Bakire ve Çocuk Azizelerle, 1472-1474, T.ü.y.b, 248x170cm, T.ü.y.b, Brera Sanat Galerisi /Milan, İtalya Hatice Karadoğan'1n yüksek Lisans tezi

Görsel 44: Raffael'in, Atina Okulu, 1510-11, Fresk, Stanza della Segnatura, Vatikan/ Roma İtalya ve resmin geometrik kurgusu. Hatice Karadoğan'ın yüksek Lisans tezi 
Görsel 45:Raffael'in "Atina Okulu" resminde bir detay; Öklid, elinde pergel ve Pisagor deftere bir şeyler yazıyor

Görsel 46: Tang Yin, Şair ve iki fahişe,16.yy., T.ü.y.b., Ulusal Saray Müzesi/ Taipe - Tayvan

Görsel 47: Leonardo da Vinci, Mona Lisa, 1503, T.ü.y.b., 77 x 53 cm, Musée du Louvre / Paris Fransa, altın oran içeren "Mona Lisa" resmi ve şemaları

Görsel48:Michelangelo Bounarroti, Kutsal Aile, 1505, A.ü.t., 120 x $120 \mathrm{~cm}$, Uffizi Galeri / Floransa - İtalya ( Michelangelo'n'nun altın oran içeren “Kutsal Aile" resmi ve pentagram şeması) Hatice Karadoğan'ın yüksek Lisans tezi

Görsel 49:Tintoretto, Markus’un cesedini kurtarma, 1562/66, T.ü.y.b., 421 x 306 cm, Akademi Galerisi / Venedik - İtalya

Görsel 50: El Greco,Saint Joseph And The Christ Child, 1597-99 (oil on canvas) 109 X56 cm

https://commons.wikimedia.org/wiki/File Çobanların Duası, 1610, T.ü.y.b., 319 x 180 cm, Prado Müzesi / Madrid - İspanya

Görsel 51: Andrea Pozzo, Cizvitlerin Misyonerliğine Alegori,1661. San Lgnazio Kilisesi’nde tavan resmi, Roma ve Resmin Geometrik Analizi( Hatice Karadoğan'ın yüksek Lisans tezi)

Görsel 52: Cezanne, Avenue at Chantilly 1888,yağlıboya,82x66cm, National Gallery, London https://commons.wikimedia.org/wiki/File:Paul_C\%C3\%A9zanne_-_

Görsel 53: El Lissitzky, Suprematizm,, 1920 - 1929, 81 x 60 cm. http://www.artnet.com/artists/el-lissitzky/supermatismo-WSFCZG8BenvIDYtkv$\operatorname{rnjg} 2$

Görsel 54:Victor Vasarely, 1968, Keple Gestalt, T.ü.a.b., 160 x 160cm ve geometrik kurgu şemas1

Görsel 55: Rene Magritte, Boş Görünce ( The Blank Seeing), 1965, T.ü.y.b., 81x65cm, Ulusal Sanat Galerisi,Washington D.C( Hatice Karadoğan'1n yüksek Lisans tezi)

Görsel 56: Maurits Cornelius Escher, "Öteki Dünya” ağaç gravür ve ağaç baskı, 1947 ve resmin geometrik analizi Hatice Karadoğan'1n yüksek Lisans tezi 